\title{
Tracking Fungal Growth: Establishment of Arp1 as a Marker for Polarity Establishment and Active Hyphal Growth in Filamentous Ascomycetes
}

\author{
Anika Groth ${ }^{1}$, Carolin Schunke ${ }^{1,2}$, Eva Johanna Reschka ${ }^{1}$, Stefanie Pöggeler ${ }^{1, *(D)}$ \\ and Daniela Elisabeth Nordzieke ${ }^{1, *}$ (D) \\ 1 Institute of Microbiology and Genetics, Genetics of Eukaryotic Microorganisms, Georg-August-University \\ of Göttingen, Grisebachstr. 8, 37077 Göttingen, Germany; anika.gibron@stud.uni-goettingen.de (A.G.); \\ carolin.schunke@bzh.uni-heidelberg.de (C.S.); evareschka@gmx.net (E.J.R.) \\ 2 Biochemistry Center, Heidelberg University, Im Neuenheimer Feld 328, 69120 Heidelberg, Germany \\ * Correspondence: spoegge@gwdg.de (S.P.); dnordzi@gwdg.de (D.E.N.)
}

Citation: Groth, A.; Schunke, C.; Reschka, E.J.; Pöggeler, S.; Nordzieke, D.E. Tracking Fungal Growth: Establishment of Arp1 as a Marker for Polarity Establishment and Active Hyphal Growth in Filamentous Ascomycetes. J. Fungi 2021, 7, 580. https://doi.org/10.3390/jof7070580

Academic Editor: Aaron Neiman

Received: 6 April 2021

Accepted: 18 July 2021

Published: 20 July 2021

Publisher's Note: MDPI stays neutral with regard to jurisdictional claims in published maps and institutional affiliations.

Copyright: (c) 2021 by the authors. Licensee MDPI, Basel, Switzerland. This article is an open access article distributed under the terms and conditions of the Creative Commons Attribution (CC BY) license (https:/ / creativecommons.org/licenses/by/ $4.0 /)$.

\begin{abstract}
Polar growth is a key characteristic of all filamentous fungi. It allows these eukaryotes to not only effectively explore organic matter but also interact within its own colony, mating partners, and hosts. Therefore, a detailed understanding of the dynamics in polar growth establishment and maintenance is crucial for several fields of fungal research. We developed a new marker protein, the actin-related protein 1 (Arp1) fused to red and green fluorescent proteins, which allows for the tracking of polar axis establishment and active hyphal growth in microscopy approaches. To exclude a probable redundancy with known polarity markers, we compared the localizations of the Spitzenkörper (SPK) and Arp1 using an FM4-64 staining approach. As we show in applications with the coprophilous fungus Sordaria macrospora and the hemibiotrophic plant pathogen Colletotrichum graminicola, the monitoring of Arp1 can be used for detailed studies of hyphal growth dynamics and ascospore germination, the interpretation of chemotropic growth processes, and the tracking of elongating penetration pegs into plant material. Since the Arp1 marker showed the same dynamics in both fungi tested, we believe this marker can be broadly applied in fungal research to study the manifold polar growth processes determining fungal life.
\end{abstract}

Keywords: Arp1; polarity; microscopy; Sordaria macrospora; Colletotrichum graminicola; chemotropism

\section{Introduction}

Polar tip growth as a form of cell extension is widespread in eukaryotes and can be found in neurons, root hairs, pollen tubes, and at the apex of fungal hyphae [1,2]. In fungi, polar growth allows for not only radial growth but also hyphal network formation by branching followed by the targeted fusion of fungal cells [3,4]. Furthermore, the apical growth direction can be adapted by the sensing of light, physical contact, electrical currents, and chemicals, including nutrients, pheromones, and host-derived signals [5,6]. For plant-interacting symbionts and pathogens, the penetration peg formation and elongation outgoing from appressoria, hyphopodia (or so-called expressoria recently identified in Epichloë festucae) requires strict polar growth [7-11].

Before apical growth can start, cell polarity that enables the asymmetrical transport of cellular components for cell wall and plasma membrane extension must be established [1,12-14]. The recruitment of Rho-GTPase Cdc42 to the new polarity site is crucial for this process [13,15-18]. After Cdc42 accumulation, factors such as the septins and homologs of the yeast formin Bni1 are located on the new polar axis followed by the formation of actin or septin rings, respectively [19-24]. As work on Neurospora crassa has shown, a second Rho-GTPase, Rac1, is recruited to the polar site and regulates chemotropic growth processes, including germling and hyphal fusion [25]. A prominent molecular structure 
correlated to hyphal polarity is the Spitzenkörper (SPK), a dark-phase structure close to the hyphal tip. Actin cables and microtubules (MTs), which are surrounded by vesicles either bound for fusion with the plasma membrane at the hyphal apex or endocytic vesicles involved in the recycling of membranes and proteins, are central to the SPK $[11,13,26-28]$.

At a polar growing hypha, outward- and inward-bound traffic meet. This requires specific transportation systems for the coordination of stable polar growth [29]. Though actin and their motor protein myosin mediate short-distance transport from the SPK to the plasma membrane, long distance transport to the SPK takes places along MTs [1]. In filamentous fungi, MTs are polar structures that show a bidirectional polarity inside mature hyphae and clear plus-end polarity in the apical region [30-32]. Conserved among the eukaryotic kingdoms of life, the minus-end directed transport along MTs is dependent on the interaction of the multisubunit complexes dynein and dynactin [33]. Though dynein is the motor sitting on the MTs, different cargos are linked to the motor by dynactin. Dynactin is composed of a projecting sidearm, which interacts with the dynein motor, and a $37 \mathrm{~nm}$ minifilament, which binds to the cargo [33,34]. Eight monomers of actinrelated protein 1, Arp1, the protein of its class that is able to form filaments, are central to the minifilament [35-37]. As was shown for Ustilago maydis and Aspergillus nidulans, cytoplasmic dynein is recruited to the plus-ends of MTs in a kinesin-dependent manner, resulting in the formation of a dynein loading zone close to the hyphal tip [38-41]. Together, dynein and dynactin allow for endoplasmic reticulum (ER)-to-Golgi vesicle trafficking, the minus-end directed transport of organelles, late and early endosomes, protein complexes, and lipid droplets, as well as the centripetal movement of virus capsids and ER-Golgi transport complexes [32-34,42,43].

In our study, we investigated the localization dynamics of the dominant dynactin component Arp1 using protein fusion constructs with the red and green fluorescence tags of TagRFP-T and mNeonGreen (mNG), respectively. As the monitoring of Arp1 in the coprophilous fungus Sordaria macrospora and the hemibiotrophic plant pathogen Colletotrichum graminicola has shown, Arp1 fusion proteins localize to tips of expanding hyphae and the sites of polar growth establishment, whereas they are absent from non-growing hyphae and future germling fusion sites. Furthermore, dynamic dot-like localization close to nuclei has indicated a role in nuclear transport and sorting. To test for the probable applicability of fluorescent Arp1 as a polarity marker, we monitored its localization during several polar growth processes, such as vegetative polar growth, ascospore germination, chemotropic growth, and penetration hyphae elongation. We additionally compared the localization of Arp1 and the SPK by co-staining with FM4-64. As our results showed, the usage of the Arp1 marker protein allows for dynamic growth processes to be followed in saprophytic and pathogenic fungal species, and it enables an improved assessment of chemotropic growth analyses. Since the Arp1 marker protein has overlapping but not identical localization characteristics compared with the SPK, we believe it will be a valuable extension to existing marker proteins.

\section{Materials and Methods}

\subsection{Strains, Media and Growth Conditions}

For the cloning and propagation of recombinant plasmids, Escherichia coli strain MACH1 (Thermo Fisher Scientific, Waltham, MA, USA) was used in standard culture conditions [44]. To generate recombinant plasmids via homologous recombination in yeast, positive transformants of Saccharomyces cerevisiae strain PJ69-4A were selected for uracil prototrophy $[45,46]$.

S. macrospora wild-type strain DSM977 was transformed with recombinant plasmids according to the standard protocol [47]. Positive transformants were selected on media containing nourseothricin-dihydrogen sulphate $(50 \mu \mathrm{g} / \mathrm{mL}$, nat) (Jena Bioscience $\mathrm{GmBH}$, Jena, Germany) and/or hygromycin B (110 U/mL, hyg) (Merck, Kenilworth, NJ, USA). S. macrospora strains were grown on liquid or solid biomalt maize medium (BMM) under continuous light conditions at $27^{\circ} \mathrm{C}$ [48-50]. Crosses of S. macrospora strains were 
performed as described previously [51]. After incubation for 7-10 d, plates were topped with an agar-plate containing nourseothricin and hygromycin B to select positive singlespore isolates.

The wild-type CgM2 strain (M1.001) of C. graminicola (Ces.) G. W. Wilson (teleomorph Glomerella graminicola) was used in this study [52]. For the generation of falcate conidia, C. graminicola was grown on oat meal agar (OMA) for $14-21 \mathrm{~d}$ at $23^{\circ} \mathrm{C}$ [10]. Oval conidia, used as the basis for $C$. graminicola transformation and experimental procedures, were obtained in shaking cultures in a liquid complete medium with $0.5 \mathrm{M}$ of sucrose (CMS) for two days ( $80 \mathrm{rpm}$ and $23^{\circ} \mathrm{C}$ ), followed by $5-8$ days of incubation in darkness [53]. For the selection of successful transformants and growth analyses, a complete medium (CM) containing nourseothricin-dihydrogen sulphate $(150 \mu \mathrm{g} / \mathrm{mL}$, nat; Jena Bioscience $\mathrm{GmBH}$, Jena, Germany) or geneticin disulphate (G418, $400 \mu \mathrm{g} / \mathrm{mL}$, gen; Carl Roth GmbH \& Co. KG, Karlsruhe, Germany) was used when appropriate.

Details about all used strains are given in Table 1.

\subsection{Multiple Sequence Alignment of Fungal Arp1}

Multiple sequence alignments of protein sequences and neighbor joining phylogenetic analysis were performed with MAFFT version 7 [54]. A bootstrap analysis was conducted with 1000 iterations to test the tree for statistical significance. The tree was displayed with Archaeopteryx.js [55].

\subsection{Construction of Plasmids}

Plasmids were generated via homologous recombination in S. cerevisiae [45], as described previously [56], or the NEBuilder HiFi DNA Assembly Cloning Kit (New England Biolabs, Ipswich, MA, USA) according to the instruction manual. Information on all primer sequences and plasmids is provided in Tables $\mathrm{S} 1$ and S2, respectively.

For the construction of the pArp1-KO knockout plasmid, the Golden Gate cloning system according to Dahlmann et al., 2020, was used [57]. The 5'-(1311 bp) and $3^{\prime}-(1791 \mathrm{bp})$ flanking regions of the Smarp1 gene were amplified from S. macrospora wt gDNA with the Arp1-ko-5f/Arp1-ko-5r and Arp1-ko-3f/Arp1-ko-3r primer pairs, respectively. Together

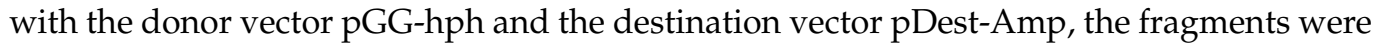
cloned via the Golden Gate procedure [57].

To generate the $\mathrm{pSmarp} 1$ plasmid, a fragment $(5028 \mathrm{bp}$ ) containing the native promotor, coding sequence and native terminator of Smarp1 was amplified from S. macrospora wt gDNA with the Arp1-nat-5f/Arp1-nat-3r primer pair. The fragment was cloned into the XhoI-linearized pRS-nat vector [58] via homologous recombination using the PJ69-4A yeast strain [45].

The fragment containing the native promoter and coding sequence of Smarp 1 was amplified from S. macrospora wt gDNA using the Arp1_promotor_f/Arp1-Neo_r primer pair for the generation of the pSmarp1-mNG plasmid. The amplification of $m N G$ was done with the Neo_f/Neo_TtrpC_r primer combination using the pmn-xyl plasmid [59]. The terminator of the anthranilate synthase gene $\operatorname{trp} C$ of Aspergillus nidulans, $\operatorname{TtrpC}$, was amplified from the p1783-1 plasmid [60] with the TtrpC_f/TtrpC_pRS_r primer pair. The three PCR products were cloned into $\mathrm{Xhol}$-linearized vector pRS-nat [58] via homologous recombination in the PJ69-4A yeast strain [45]. To construct the pSmarp1-TagRFP-T_nat/_hyg plasmids, the Smarp1 promoter and coding sequence was amplified with the Arp1_5'f/Arp1_RFP_r primer pair from $S$. macrospora wt gDNA. The TagRFP-T sequence and the A. nidulans TtrpC were amplified using the primer pairs of RFP-f/RFP-r-trpC from pTagRFP-T_nat [61] and TrpC_F/pRS426GFPrev from p1783-1 [60], respectively. The S. cerevisiae strain PJ69-4A was transformed with the three amplicons and XhoI-linearized pRS-hyg [62] or pRS-nat [58] to generate recombinant plasmids via homologous recombination $[45,46]$.

For the generation of the pCgarp1-TagRFP-T plasmid, three fragments were amplified for the assembly with pJet1.2 (Thermo Fisher Scientific, Waltham, MA, USA) using the NEBuilder HiFi DNA Assembly Cloning Kit (New England Biolabs). Cgarp1, including the 
$1 \mathrm{~kb} 5^{\prime}$ region, was amplified from CgM2 gDNA using the 5'CgArp1_pJet_fw/CgArp1_rev oligonucleotides. The coding sequence of TagRFP-T, including the TtrpC terminator of A. nidulans, was obtained from pSmarp1-TagRFP-T (TagRFP-T_CgArp1_fw/TtrpC_r). The neomycin phosphotransferase nptII resistance cassette, was amplified from the pII99 plasmid [63] using nptII_TtrpC_fw/PtrpC_pJet_rev. For further subcloning, EcoRV restriction sites were integrated in the oligonucleotide sequences of $5^{\prime} \mathrm{CgArp1}$ _pJet_fw and nptII_TtrpC_fw. Outgoing from pCgarp1-TagRFP-T, the pJet_gen plasmid harboring the nptII-resistance cassette was generated via hydrolysis with $E c o R V$ and subsequent ligation of the plasmid backbone.

Primers were synthesized by Sigma-Aldrich Chemie GmbH (Taufkirchen, Germany). The DNA sequencing of the plasmids was performed by Seqlab Sequence Service Laboratories $\mathrm{GmbH}$ (Göttingen, Germany).

\subsection{Generation of the Smarp1 Deletion Strain $\Delta$ Smarp1}

To delete the S. macrospora arp1 gene, the pArp1-KO knockout plasmid was used as a template to amplify the 4568 bp deletion cassette with the GG_KO_fw/GG_KO_rv primer pair containing the $5^{\prime}$ - and $3^{\prime}$ - flanking regions of Smarp 1 and the $h p h$ cassette. After the PCR clean-up of the amplicon, the $S$. macrospora $\Delta$ Smku70 strain was transformed with the deletion cassette to replace the Smarp1 ORF with the $h p h$-cassette. Primary transformants were crossed with the spore-color mutant fus1-1 (S23442) [64], and single-spore isolates (ssi) of $\Delta$ Smarp1 carrying hygromycin resistance were selected [51]. The verification of the absence of the Smarp1 gene and the integration of the $h p h$-cassette at the desired locus were performed with the Arp1-v5f/h3 (1578 bp) and Arp1-v5f/Arp1-vORF5-r (2170 bp) primer pairs, respectively. To check the presence of the $S m k u 70$ gene in $\Delta$ Smarp1 after crossing, the Smku70-v1-f/ku70-ko-v3f(R) (2851 bp) primer pair was used. The deletion of $\Delta$ Smarp1 was verified via Southern hybridization hydrolyzing the gDNA of $S$. macrospora $\mathrm{wt}, \Delta \mathrm{Smku} 70$, and $\Delta$ Smarp1 with $E c o R V$. After electrophoresis, a capillary blot with a nylon membrane was performed at RT overnight. The 1791-bp 3'-probe was amplified from S. macrospora wt gDNA with the Arp1-ko-3f/Arp1-ko-3r primer pair. The labeling of probes for Southern blot experiments was done using the Amersham AlkPhos Direct Labelling and Detection Kit (GE Healthcare, Amersham RPN3680, Boston, MA, USA). Detection was performed according to the manufacturer's manual. Signals were visualized on X-ray films (Amersham Hyperfilm TM ECL; GE Healthcare, Boston, MA, USA) using an "Optimax X-ray film processor" (PROTEC GmbH \& Co. KG, Oberstenfeld, Germany).

The complementation of $\Delta$ Smarp1 was performed by transformation with the pSmarp1TagRFP-T_nat plasmid or its untagged Arp1 version, pSmarp1, resulting in the $\Delta$ Smarp1::Smarp1TagRFP-T or $\Delta$ Smarp1::Smarp1 strains, respectively. Positive primary transformants were selected on BMM supplemented with nourseothricin and hygromycin. Crosses were performed as described previously [51].

Table 1. Strains used in this study.

\begin{tabular}{|c|c|c|}
\hline Name of Strain & Genotype & Reference \\
\hline \multicolumn{3}{|l|}{ Sordaria macrospora } \\
\hline DSM997 & S. macrospora wild-type (wt) & DSMZ \\
\hline S23442 & $\begin{array}{l}\text { mutation in fus1-1 gene, brownish } \\
\text { ascospores, fertile }\end{array}$ & [64] \\
\hline fus::RH2B & 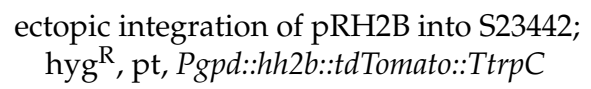 & [65] \\
\hline wt::TagRFP-T & $\begin{array}{l}\text { ectopic integration of ptRFP_nat into } \\
\text { DSM997; nat }{ }^{\mathrm{R}} \text {, ssi, Pccg1::TagRFP-T::TtrpC }\end{array}$ & [61] \\
\hline wt::GG-C-F-mNG & $\begin{array}{c}\text { ectopic integration of pGG-C-F-mNG in } \\
\text { DSM997; nat }{ }^{\mathrm{R}} \text {, ssi, } \\
\text { Pgpd::mNG::3xFLAG::TtrpC }\end{array}$ & [59] \\
\hline
\end{tabular}


Table 1. Cont.

\begin{tabular}{|c|c|c|}
\hline Name of Strain & Genotype & Reference \\
\hline$\Delta$ Smku70 & $\Delta$ Smku70::nat ${ }^{\mathrm{R}}$, fertile & [66] \\
\hline Sm::Smarp1-TagRFP-T & $\begin{array}{l}\text { ectopic integration of pSmarp1-TagRFP-T } \\
\text { in DSM997; hyg }{ }^{\mathrm{R}} \text {, ssi, } \\
\text { Smarp1P::Smarp1::TagRFP-T::TtrpC }\end{array}$ & this study \\
\hline Sm::Smarp1-mNG & $\begin{array}{l}\text { ectopic integration of pSmarp1-mNG in } \\
\text { DSM997; nat }{ }^{\mathrm{R}} \text {, ssi, } \\
\text { Smarp1P::Smarp1::mNG::TtrpC }\end{array}$ & this study \\
\hline$\Delta$ Smarp1 & $\Delta$ Smarp1::hyg ${ }^{\mathrm{R}}$, sterile & this study \\
\hline$\Delta$ Smarp1::Smarp1 & $\begin{array}{c}\text { ectopic integration of pSmarp1 in } \\
\Delta \text { Smarp1; hyg }{ }^{\mathrm{R}}, \text { nat }^{\mathrm{R}}, \mathrm{ssi}, \\
\text { Smarp1P::Smarp1::Smarp1T }\end{array}$ & this study \\
\hline$\Delta$ Smarp1::Smarp1-TagRFP-T & $\begin{array}{l}\text { ectopic integration of pSmarp1-TagRFP-T } \\
\text { in } \Delta \text { Smarp1; hyg }{ }^{\mathrm{R}} \text {, nat }{ }^{\mathrm{R}} \text {, ssi, } \\
\text { Smarp1P::Smarp1::TagRFP-T::TtrpC }\end{array}$ & this study \\
\hline \multicolumn{3}{|l|}{ Colletotrichum graminicola } \\
\hline CgM2 & $\begin{array}{l}\text { C. graminicola wild-type (wt); also } \\
\text { referred to as M1.001 }\end{array}$ & {$[67]$} \\
\hline CgM2::Smarp1-mNG & $\begin{array}{l}\text { ectopic integration of pSmarp1-mNG in } \\
\text { CgM2; nat }{ }^{\mathrm{R}} \text {, ssi, } \\
\text { Smarp1P::Smarp1::mNG::TtrpC }\end{array}$ & this study \\
\hline CgM2::Cgarp1-TagRFP-T & $\begin{array}{l}\text { ectopic integration of pCgarp1-TagRFP-T } \\
\text { in CgM2; gen }{ }^{\mathrm{R}} \text {, ssi, } \\
\text { Cgarp1P::Cgarp1::TagRFP-T::TtrpC }\end{array}$ & this study \\
\hline \multicolumn{3}{|c|}{$\begin{array}{l}\text { nat }^{\mathrm{R}} \text { : nourseothricin resistant; hyg }{ }^{\mathrm{R}} \text { : hygromycin resistant; gen }{ }^{\mathrm{R}} \text { : geneticin disulphate resistant; ssi: single-spore } \\
\text { isolate; pt: primary transformant; } P \text { : promotor region; TtrpC: terminator of the anthranilate synthase gene of } \\
\text { A. nidulans; Pccg1: promoter of the clock controlled gene } 1 \text { of } N \text {. crassa; Pgpd: promoter of the glyceraldehyde-3- } \\
\text { phosphate dehydrogenase gene of A. nidulans; } m N G \text { : gene for green fluorescence protein monomeric NeonGreen } \\
\text { (mNG) of Branchiostoma lanceolatum; } \text { tdTomato: gene encoding red fluorescence protein tdTomato from Discosoma } \\
\text { species; TagRFP-T: gene for red fluorescence protein TagRFP-T of Entacmaea quadricolor; } h \text { h } 2 b \text { : gene for histone } 2 \mathrm{~b} \text {. }\end{array}$} \\
\hline
\end{tabular}

\subsection{Generation of S. macrospora Strains for Fluorescence Microscopy}

Strains were generated by transforming wt $S$. macrospora, as described previously [47]. The ectopic integration of the pSmarp1-TagRFP-T and pSmarp1-mNG plasmids led to the selection of positive transformants on BMM supplemented with nourseothricin-dihydrogen sulphate $(50 \mu \mathrm{g} / \mathrm{mL})$ and/or hygromycin B $(110 \mathrm{U} / \mathrm{mL})$ (Merck, Kenilworth, NJ, USA). Primary transformants were grown over $7-9 \mathrm{~d}$ at $27^{\circ} \mathrm{C}$ to obtain single-spore isolates, as described previously [51].

\subsection{Generation of C. graminicola Strains}

The pCgarp1-TagRFP-T and pSmarp1-mNG plasmids were linearized using NotI and $\mathrm{NdeI}$, respectively, prior to transformation in CgM2. Protoplasts were obtained from oval conidia by cell wall digestion using a lysis enzyme of Trichoderma harzianum, as described previously [10]. To obtain homokaryotic transformants, colonies that had developed on CM plates supplemented with $400 \mu \mathrm{g} / \mathrm{mL}$ geneticin disulphate (pCgarp1-TagRFPT) or $150 \mu \mathrm{g} / \mathrm{mL}$ nourseothricin-dihydrogen sulphate (pSmarp1-mNG) were allowed to conidiate on OMA. After single-spore isolation using the generated falcate conidia, resistant transformants were tested for the expression of the red or green fluorescent Arp1 fusion proteins by fluorescence microscopy.

\subsection{Fluorescence Microscopy}

Microscopic documentation was performed with the AxioImager M1 microscope (Zeiss, Jena, Germany) with differential interference contrast (DIC) and specific filter 
sets for the detection of the fluorescent signals. Image capturing was performed with a Photometrix CoolSNAP HQ camera (Roper Scientific, Photometrics, Tucson, AZ, USA), and images were processed using ZEISS ZEN Digital Imaging (version 2.3; Zeiss). To detect the mNG signal, a 49002 Chroma filter set (exciter ET470/40x, ET525/50m, beam splitter T495lpxr) was used, and for tdTomato/TagRFP-T/FM4-64 signals, a 49005 Chroma filter set (exciter ET545/30x, emitter ET620/60 m and beam splitter T570LP) was used. For each experiment, at least three biological replicates were analyzed more than three times.

For the investigation of $S$. macrospora hyphae, the strains were grown for $24 \mathrm{~h}$ on BMM-covered glass slides and $2 \mathrm{~mL}$ of liquid BMM on top under continuous light at $27^{\circ} \mathrm{C}$. For FM4-64 (Thermo Fisher Scientific, Waltham, MA, USA) staining, the Sm::Smarp1-mNG strain was grown on solid BMM supplemented with $1.5 \%$ agarose (Biozym Scientific $\mathrm{GmbH}$, Hessisch Oldendorf, Germany) at $27^{\circ} \mathrm{C}$ under continuous light conditions for $24 \mathrm{~h}$. Then, $100 \mu \mathrm{L}$ of an FM4-64 solution $(1 \mu \mathrm{g} / \mathrm{mL}$ in distilled water) was applied to the mycelium on the agar-piece and incubated for $15 \mathrm{~min}$ at $37^{\circ} \mathrm{C}$. For nuclei staining, DAPI (AppliChem, Darmstadt, Germany) was dissolved in distilled water to a stock solution of $1 \mathrm{mg} / \mathrm{mL}$ and further diluted with methanol to a concentration of $1 \mu \mathrm{g} / \mathrm{mL}$. Incubation took place in the dark at $37^{\circ} \mathrm{C}$ for $2-3 \mathrm{~min}$. For time lapse studies of growing hyphae, S. macrospora strains were grown on BMM or Sordaria Westergaard (SWG) fructification medium [48-50] supplemented with $1.5 \%$ agarose (Biozym Scientific $\mathrm{GmbH}$, Hessisch Oldendorf, Germany) under continuous light conditions for $24 \mathrm{~h}$ at $27^{\circ} \mathrm{C}$. For the analysis of SmArp1-mNG localization during ascospore germination, the wt::Smarp1-mNG $x$ fus::RH2B strain was grown on BMM over 7-9 d, and discarded spores were washed down with $0.02 \%$ Tween 20. Ascospores were then plated on BMM containing 1.5\% agarose, and pieces were cut out and analyzed under the fluorescence microscope after 3-4 h. Recording interval of $5 \mathrm{~s}$ over 20 min were used for time lapse studies. To analyze Arp1-mNG localization at nuclei, the ratio of Arp1-mNG localization close to a nucleus to the total number of nuclei was estimated for the 36 single pictures, thus resulting in Video S2.

The recording of C. graminicola hyphae expressing the Arp1 of S. macrospora Cterminally fused to $\mathrm{mNG}$ was performed after incubation for $3 \mathrm{~d}$ at $23^{\circ} \mathrm{C}$ on $\mathrm{CM}$ covered with cellophane. The staining of these hyphae with FM4-64 (Thermo Fisher Scientific, Waltham, MA, USA) was done by the application of $100 \mu \mathrm{L}$ of a $1 \mu \mathrm{g} / \mathrm{mL}$ working solution on the growing mycelium, followed by incubation for $15 \mathrm{~min}$ at $37^{\circ} \mathrm{C}$. For the analysis of Cgarp1-TagRFP-T localization during early germination and germling fusion, $50 \mu \mathrm{L}$ of oval conidia $\left(\mathrm{c}=5 \times 10^{7} / \mathrm{mL}\right)$ were spread on water agar $(1 \%$ agarose, $1 \%$ Serva agar, and $25 \mathrm{mM} \mathrm{NaNO}_{3}$ ). Incubation took place for $2 \mathrm{~h}$ (monitoring of young germlings) or $6 \mathrm{~h}$ (monitoring of CAT fusions and older germlings) at $23^{\circ} \mathrm{C}$. For time lapse studies of young germlings, a recording interval of 5 min was used. To track Cgarp1-TagRFP-T localization during plant penetration, a heat-inactivated onion epidermis covering water agar (1\% agarose and $1 \%$ Serva agar) was inoculated with $10 \mu \mathrm{L}$ drops containing $10^{3}$ oval conidia in $0.01 \%$ Tween for $29 \mathrm{~h}$ at $23{ }^{\circ} \mathrm{C}$ [68]. Different layers of an infected onion epidermis were recorded at a fixed distance of $0.5 \mu \mathrm{m}$. All experiments were performed with a minimum of three independent replicates.

\subsection{Analysis of Chemotropic Growth Using the Arp1-TagRFP-T Marker}

The application of Cgarp1-TagRFP-T for the analysis of chemotropic growth was performed by confronting germlings derived from $C$. graminicola oval conidia $\left(c=5 \times 10^{5} / \mathrm{mL}\right)$ with a growing gradient of $50 \mathrm{mM}$ glucose using a 3D-printed device, as described previously [69]. After $6 \mathrm{~h}$ of incubation at $23^{\circ} \mathrm{C}$ with a minimum of 40 germlings/experiment, whether the tips of fungal germlings were growing to the established glucose gradient or to the solvent control (water) was determined. To allow for the discrimination of active growing germlings and to include non-germinated conidia with an established polar axis in the analysis, the localization of the Arp1-TagRFP-T maker was also tracked. In the final analysis, only germlings and conidia with a clear Arp1-TagRFP-T localization at the tip or a distinct cellular site were evaluated, respectively. In the case that one germling showed 
Arp1-TagRFP-T localization at two tips, only individuals with a preferred growth direction were included into the analysis. From the obtained numbers, the chemotropic growth rate was calculated as described previously [69]. All experiments were performed with a minimum of five independent replicates. For statistical analyses, the t-test for equal variances was used for all displayed experiments.

\subsection{Protein Sample Preparation and Western Blot Hybridization}

S. macrospora strains were cultivated in liquid BMM and grown for $3 \mathrm{~d}$ at $27{ }^{\circ} \mathrm{C}$ to extract proteins from fungal mycelium. After harvesting, drying, and grinding the mycelium in liquid nitrogen, $520 \mu \mathrm{L}$ of lysis buffer $(10 \mathrm{mM}$ Tris- $\mathrm{HCl} \mathrm{pH} 7.5,150 \mathrm{mM} \mathrm{NaCl}$, $0.5 \mathrm{mM}$ EDTA pH 8.0, $1 \mathrm{mM}$ PMSF, $2 \mathrm{mM}$ DTT, $0.5 \% \mathrm{NP}-40,1 \times$ protease inhibitor cocktail IV (1 tbl/50 mL, 04693132001, Mannheim, Germany), and 1× PhosSTOP ${ }^{\text {TM }}(1 \mathrm{tbl} / 10 \mathrm{~mL}$, Roche, Mannheim, Germany))/g mycelium powder were added. Together with about $200 \mu \mathrm{L}$ of glass beads ( $\varnothing 0.25-0.5 \mathrm{~mm}$; Roth $\mathrm{GmbH}$, Karlsruhe, Germany), cells were lysed in the TissueLyser (Qiagen, Hilden, Germany) at $30 \mathrm{Hrz}$ for $2 \mathrm{~min}$. Subsequently, cells were separated from debris by centrifugation at $10,000 \mathrm{rpm}$ for $15 \mathrm{~min}$ at $4{ }^{\circ} \mathrm{C}$ and were prepared for Western Blot analysis by adding $4 \times$ NuPAGE $^{\circledR}$ LDS-SB (Thermo Fisher Scientific, Waltham, MA, USA) and 1 M DTT to the crude extract. After heating of the samples for $10 \mathrm{~min}$ at $70{ }^{\circ} \mathrm{C}, 25 \mu \mathrm{L}$ were loaded on a $12 \%$ SDS gel. As a protein standard, the Nippon Genetics Co. Europe blue star pre-stained protein marker (NIPPON Genetics Europe, Düren, Germany) was used.

Blotting was performed using the AmershamTM ProtranTM Nitrocellulose Blotting Membrane (GE Healthcare, Little Chalfont, UK) with $1 \times$ transfer buffer and a Mini TransBlot $^{\circledR}$ Cell device, as described by the manufacturer (Bio-Rad Laboratories, Hercules, CA, USA) [70]. The nitrocellulose membrane was blocked with $5 \%(w / v)$ skim milk powder in $1 \times$ Tris-buffered saline supplemented with $0.05 \%$ Tween $20^{\circledR}$ (TBST) for $1 \mathrm{~h}$ at RT. To detect antigen-antibody reactions, a primary TagRFP-T (rabbit) -antibody (1:12,500, BioCat (Evrogen, Moscow, Russia), AB233-ev) solved in 5\% skim milk/TBST was used. After removing the primary antibody, the membrane was washed three times with $1 \times$ TBST for $15 \mathrm{~min}$, and a horse-radish peroxidase (HRP)-coupled secondary anti rabbit-antibody (1:5000, Thermo Fisher Scientific, Waltham, MA, USA) was applied to the membrane for $1 \mathrm{~h}$ at RT. To detect the HRP-coupled antibodies, the ImmobilonTM Western HRP Substrate kit (Merck, Kenilworth, NJ, USA) was used. Signals were visualized on X-ray films (Amersham Hyperfilm TM ECL, Marlborough, MA, USA) using an "Optimax X-ray film processor" (PROTEC GmbH \& Co. KG, Oberstenfeld, Germany).

\subsection{Phenotypic Analysis}

To define growth behavior and sexual development, S. macrospora strains were grown on solid SWG medium over $10 \mathrm{~d}$ and documented with a VHX-500F Digital Microscope (Keyence, Osaka, Japan). For growth-rate determination, six replicates each of S. macrospora wt strain, Sm::Smarp1-TagRFP-T and Sm::Smarp1-mNG, were grown in 30-cm race tubes filled with solid SWG medium over $7 \mathrm{~d}$ under continuous light at $27^{\circ} \mathrm{C}$. After $3 \mathrm{~d}$, the growth front was marked every day at the same time to determine the growth velocity in $\mathrm{cm} /$ day.

For the determination of the $C$. graminicola growth rate, defined mycelial plugs of CgM2, CgM2::Arp1-TagRFP-T, and CgM2::SmArp1-mNG from pre-cultures were transferred to fresh CM plates without selection. After $3 \mathrm{~d}$, the growth area was recorded using an Epson Perfection V600 Photo scanner in four subsequent days. The optical evaluation of the growth area was done using the measuring tool of Fiji [71] on scaled images. The growth rate of four replicates was determined by the difference of the growth area of two subsequent days in $\mathrm{cm}^{2}$. 


\section{Results}

\subsection{Arp1 Deletion in S. macrospora Results in a Severe Growth Defect That Can Only Partially} Be Complemented

As part of the dynactin protein complex, Arp1 is highly conserved among eukaryotes. As the performed multiple sequence alignment revealed, the Arp1 protein showed a high amino-acid identify among the clades of Ascomycota, Basidiomycota, and Mucormycota in saprophytic and pathogenic species (Table 2 and Figures S1 and S2). To characterize Arp1 in S. macrospora, the $\Delta$ Smarp1 deletion strain was generated by the homologous recombination of an hph-deletion cassette flanked by upstream and downstream regions of Smarp1 (Figure S3a). The resulting $\Delta$ Smarp1 strain was verified via PCR (Figure S3b) and Southern blot analysis (Figure S3c). To investigate the sexual development of the deletion strain, together with the complementation strains compared to the wt S. macrospora, the growth behavior was analyzed over $10 \mathrm{~d}$ (Figure S4a). The life cycle of wt $S$. macrospora starts with a germinating ascospore that differentiates into a vegetative mycelium. After three more days, the female gametangia (ascogonia) are produced, and one day later, the unpigmented fruiting-body precursors (protoperithecia) are formed. These develop into melanized protoperithecia, and after self-fertilization, karyogamy, meiosis, and a postmeiotic-mitosis, they mature into pear-shaped perithecia. The developmental stages of pigmented protoperithecia and pigmented mature fruiting-bodies could be observed in the wt strains after 5-10 d (Figure S4a). In contrast, the $\Delta$ Smarp 1 strain was arrested in the formation of perithecia and displayed a slow growth velocity even after $10 \mathrm{~d}$ of incubation (Figure S4a). This severe phenotype was only partially complemented by the ectopic integration of Smarp1 with and without a fluorescence tag, although Western Blot analyses verified the expression of SmARP1-TagRFP-T in the investigated strain (Figure S4b).

Table 2. Pair-wise comparison of fungal Arp1 orthologs. Amino-acid identity is given in \% from the Clustal Omega matrix of the alignment depicted in Figure S1.

\begin{tabular}{|c|c|c|c|c|c|c|c|c|c|c|c|c|c|c|c|c|}
\hline & $\mathrm{Sm}$ & $\mathrm{Nc}$ & $\mathrm{Cg}$ & Fo & Mo & An & Ro & $\mathrm{Ml}$ & $\mathrm{Cc}_{\mathrm{C}}$ & $\mathrm{Sco}$ & $\mathrm{Cn}$ & $\mathrm{Um}$ & $\mathrm{Pc}_{\mathrm{C}}$ & $\mathrm{Sp}$ & $\mathrm{Ca}$ & $\mathrm{Sc}$ \\
\hline $\mathrm{Sm}$ & 100 & 100 & 93 & 92 & 88 & 78 & 74 & 74 & 70 & 73 & 71 & 74 & 74 & 51 & 56 & 50 \\
\hline $\mathrm{Nc}$ & & 100 & 92 & 91 & 88 & 78 & 74 & 74 & 70 & 73 & 71 & 71 & 74 & 51 & 56 & 50 \\
\hline $\mathrm{Cg}$ & & & 100 & 94 & 87 & 79 & 74 & 74 & 69 & 73 & 71 & 73 & 76 & 52 & 57 & 51 \\
\hline Fo & & & & 100 & 87 & 78 & 74 & 74 & 70 & 74 & 72 & 74 & 75 & 51 & 57 & 50 \\
\hline Mo & & & & & 100 & 78 & 74 & 75 & 69 & 70 & 70 & 73 & 74 & 51 & 59 & 52 \\
\hline An & & & & & & 100 & 73 & 74 & 68 & 72 & 71 & 71 & 71 & 50 & 58 & 51 \\
\hline Ro & & & & & & & 100 & 99 & 77 & 81 & 79 & 81 & 82 & 54 & 60 & 50 \\
\hline $\mathrm{Ml}$ & & & & & & & & 100 & 77 & 82 & 78 & 82 & 81 & 54 & 60 & 50 \\
\hline $\mathrm{Cc}_{\mathrm{c}}$ & & & & & & & & & 100 & 87 & 80 & 78 & 74 & 49 & 54 & 48 \\
\hline Sco & & & & & & & & & & 100 & 83 & 82 & 77 & 52 & 58 & 51 \\
\hline $\mathrm{Cn}$ & & & & & & & & & & & 100 & 80 & 74 & 52 & 59 & 50 \\
\hline $\mathrm{Um}$ & & & & & & & & & & & & 100 & 78 & 55 & 60 & 52 \\
\hline $\mathrm{Pc}$ & & & & & & & & & & & & & 100 & 56 & 58 & 51 \\
\hline $\mathrm{Sp}$ & & & & & & & & & & & & & & 100 & 47 & 44 \\
\hline $\mathrm{Ca}$ & & & & & & & & & & & & & & & 100 & 53 \\
\hline $\mathrm{Sc}$ & & & & & & & & & & & & & & & & 100 \\
\hline
\end{tabular}

Abbreviations: Sm, Sordaria macrospora; Nc, Neurospora crassa; Cg, Colletotricum graminicola; Fo, Fusarium oxysporum f. sp. Lycopersici; Mo, Magnaporthe oryzae; An, Aspergillus nidulans; Sc, Saccharomyces cerevisiae; Ca, Candida albicans; Pc, Pneumocystis carinii, Sp, Schizzosaccharomyces pombe; Cn, Cryptococcus neoformans var. grubii; Um, Ustilago maydis; Cc, Coprinopsis cinerea; Sco, Schizophyllum commune; Ro, Rhizopus oryzae; $\mathrm{Ml}$, Mucor lusitanicus. 


\subsection{SmArp1 Localization Is a Dynamic Process at Growing Hyphal Tips and in Proximity to the Nucleus}

Fluorescence microscopy was performed to determine the cellular localization of SmArp1-TagRFP-T. The fusion construct predominantly localizes as subapical structures in the tips of growing hyphae (Figure 1a). The application of a higher imaging contrast allowed for the further determination of dot-like structures apart from hyphal tips (Figure 1a). To confirm that the SmArp1 localization was independent of the used fluorophore, we replaced TagRFP-T by a C-terminal fused $\mathrm{mNG}$, a monomeric green fluorescent protein derived from the lancelet Branchiostoma lanceolatum [59]. SmArp1-mNG localized dynamically to growing hyphal tips (Figure S5 and Video S1). To exclude probable side effects on S. macrospora due to the expressed fusion constructs, growth rates were determined using race tubes. No difference in growth was seen in Sm::Smarp1-TagRFP-T $(3.5 \pm 0.29 \mathrm{~cm})$ or Sm::Smarp1-mNG $(3.1 \pm 0.31 \mathrm{~cm})$ compared to the wild-type strain $(3.4 \pm 0.27 \mathrm{~cm})$. The costaining of Sm::SmArp1-TagRFP-T with DAPI (Figure 1b) and co-expression experiments with a red fluorescent histone marker (RH2B tdTomato) were performed to address the dot-like localization pattern (Figure 1c). Both experiments showed that SmArp1-TagRFP-T localized to small dots close to nuclei that moved retrograde from the tip to the inner hypha (Figure 1c and Video S2). Moreover, the evaluation of the 36 single pictures of Video S2 revealed that $6-46 \%$ of nuclei showed a close-by SmArp1-mNG localization, emphasizing that the association of Arp1 to nuclei is a highly dynamic process.

\subsection{Dynamic Localization of Arp1 in C. graminicola}

To follow the hypothesis that Arp1 fused to a fluorescent protein can be used as a universal marker for active growing hyphae in fungi, we chose to transform the pSmarp1-mNG plasmid into the wild-type CgM2 strain of the plant pathogen C. graminicola. Comparable to S. macrospora, the expression of Smarp1-mNG resulted in a subapical localization at the hyphal tip (Figure 2a), indicating a conserved localization among ascomycetous fungi. For the detailed investigation of localization during C. graminicola development and pathogenicity, $\mathrm{CgM} 2$ was transformed with the $C$. graminicola arp1 gene (Cgarp1) fused to TagRFP-T under the control of its native promoter. The resulting CgM2::Cgarp1-TagRFP-T strain showed a highly dynamic CgArp1 localization to growing tips of germlings. Hyphae arrested in growth completely lost tip localization (Figure $2 b$ ). At the same time, new Cgarp1-TagRFP$\mathrm{T}$ patches appeared on new branching sites, following the new polar axis and indicating the current growth direction (Figure 2b and Video S3). Similar to findings for S. macrospora, the expression of both Arp1 fusion proteins did not result in aberrant growth patterns of C. graminicola transformants (CgM2: $9.9 \pm 1.7 \mathrm{~cm}^{2}$; CgM2::Smarp1-mNG: $9.8 \pm 2.2 \mathrm{~cm}^{2}$; CgM2::Cgarp1-TagRFP-T: $9.2 \pm 1.6 \mathrm{~cm}^{2}$ ). 
(a)

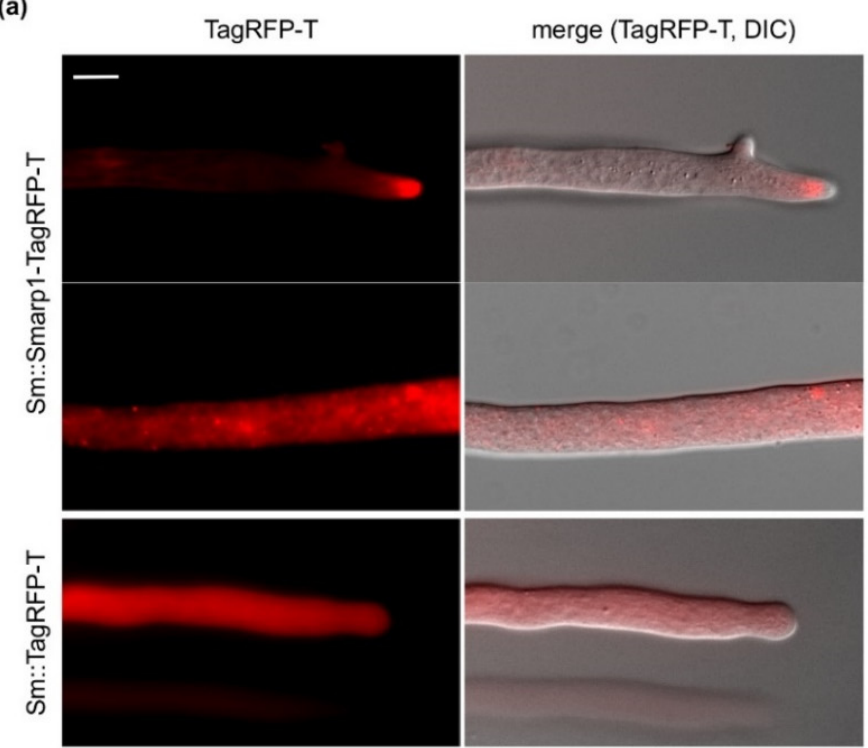

(b)

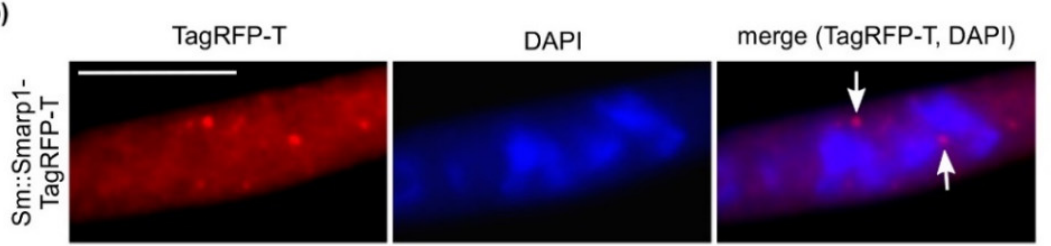

(c)

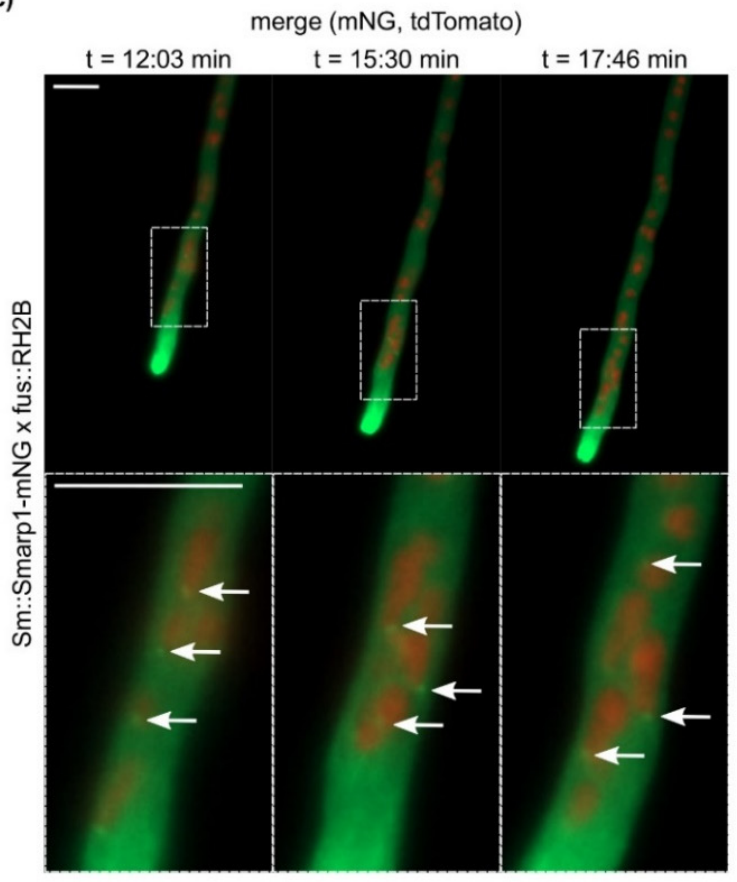

Figure 1. The localization of Arp1 in S. macrospora and the heterologous expression of pSmarp1TagRFP-T or pSmarp1-mNG in wild-type S. macrospora hyphae: a recording of hyphae from growing strains on BMM-covered glass slides $(\mathbf{a}, \mathbf{b})$ or on BMM agar supplemented with agarose (c) after incubation for $24 \mathrm{~h}$ at $27^{\circ} \mathrm{C}$. (a) SmArp1-TagRFP-T shows subapical localization at the hyphal tip and as puncta-like structures in the hyphae. TagRFP-T expression served as the control. (b) The nuclear localization of SmArp1-TagRFP-T is marked by arrows. Nuclei were stained with DAPI. (c) Selected images of Video S2 showing the dynamic localization of SmArp1-mNG in growing hyphae after $24 \mathrm{~h}$ of incubation on BMM agar at $27^{\circ} \mathrm{C}$. The nuclear localization of SmArp1-mNG is indicated by arrows. Nuclei are labeled by histone $2 \mathrm{~B}$ with tdTomato (RH2B), size bar $=10 \mu \mathrm{m}$. 
(a)

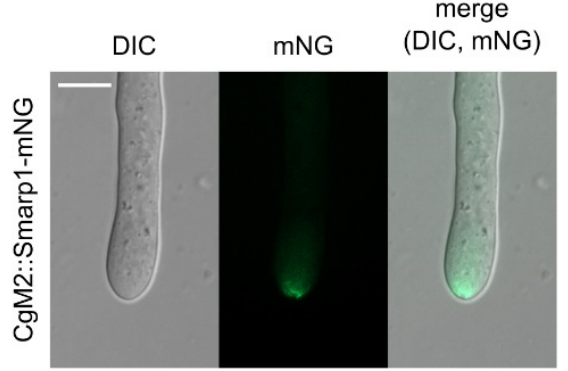

(b)

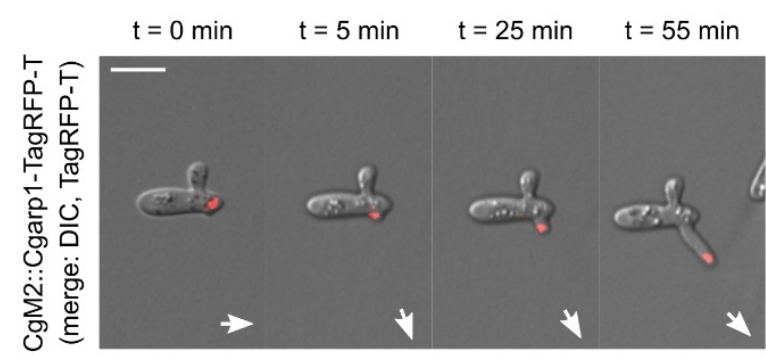

(c)

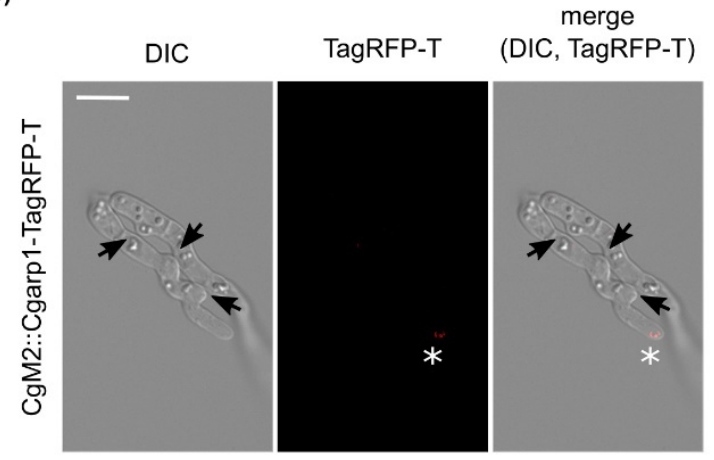

Figure 2. The localization of Arp1 in C. graminicola: (a) the heterologous expression of pSmarp1-mNG in wild-type C. graminicola CgM2 hyphae. Recording of hyphae from growing colonies on CM covered with cellophane after incubation for $3 \mathrm{~d}$ at $23{ }^{\circ} \mathrm{C}$ : (b) selected images of Video S3 showing the dynamic localization of CgArp1-TagRFP-T in growing germlings after $2 \mathrm{~h}$ of incubation on water agar at $23{ }^{\circ} \mathrm{C}$. Recording interval $=5 \mathrm{~min}$; polar growth axis is indicated by white arrows. (c) Arp1-RFP-T localization in C. graminicola germlings attempting for germling fusion. Germlings derived from oval conidia incubated for $6 \mathrm{~h}$ at $23^{\circ} \mathrm{C}$ on water agar $\left(50 \mu \mathrm{L}, \mathrm{c}=5 \times 10^{7} / \mathrm{mL}\right)$. The localization of Arp1-TagRFP-T at the tip is indicated with *. Probable future fusion sites are indicated with black arrows; size bar $=10 \mu \mathrm{m}$.

\subsection{Absence of CgArp1 localization to C. graminicola future fusion points}

Germling fusion is a highly dynamic process resulting in the formation of conidial anastomosis tubes (CATs) that link germinating conidia during early colony development [72]. This process includes the recognition of a probable fusion partner by a so-far unknown signal and the stepwise growth towards the counterpart in the chemotropic phase of the process [73]. Due to the observed correlation between CgArp1 localization to the polar sites of the fungal cell, we speculated about a probable localization in chemotropically active germlings during the CAT formation process. However, we were never able to monitor a clear localization of CgArp1 during germling interactions (Figure 2c), indicating a fundamental difference between growing hyphae and the fusion of CATs.

\subsection{Arp1 Localizes Subapical to SPK}

The SPK, a highly organized structure at the hyphal apex that is mostly composed of secretory vesicles, is broadly used to determine active hyphal growth, growth direction, germination, and branching site selection [28,74-77]. To compare the localization of Arp1 and the SPK, we stained S. macrospora strains expressing SmArp1-mNG with the red fluorescent, membrane-selective dye FM4-64 [78,79]. As depicted in Figure 3, staining with FM4-64 predominantly visualized the SPK (a dense structure at the hyphal apex) and, to a lesser extent, intracellular membranes. The overlay with SmArp1-mNG revealed that Arp1 localizes just behind the SPK, verifying its subapical localization. An analogous experiment with CgM2::Smarp1-mNG showed the same cellular localization (Figure S6). 

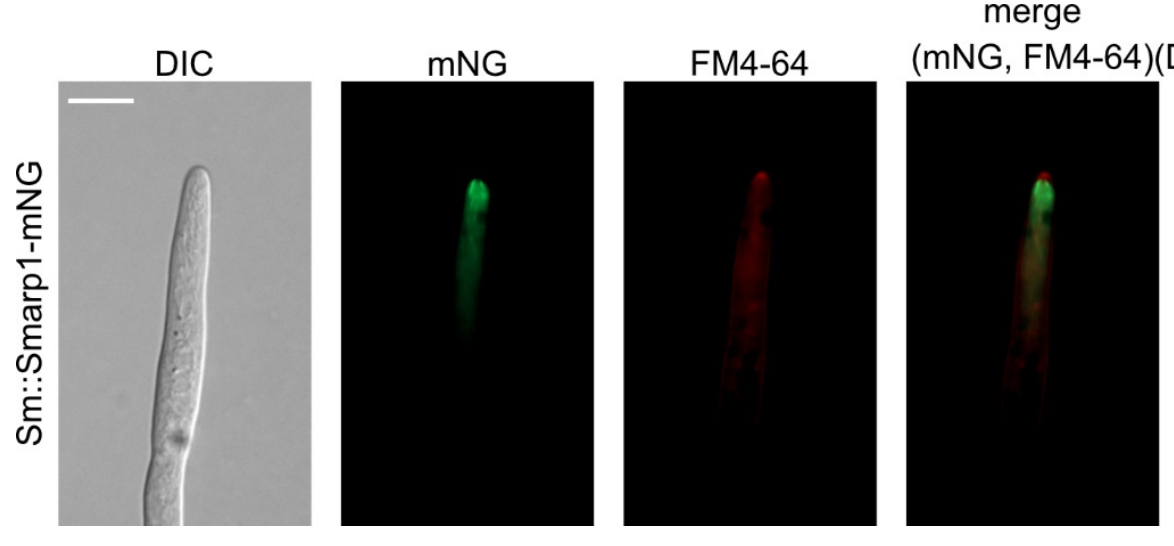

merge

Figure 3. The localization of SmArp1-mNG together with FM4-64-stained hyphae in S. macrospora. The expression of pSmarp1-mNG in wild-type $S$. macrospora hyphae stained with FM4-64 (1 $\mu \mathrm{g} / \mathrm{mL}$ in distilled water) and incubated for $15 \mathrm{~min}$ at $37^{\circ} \mathrm{C}$. The recording of hyphae was performed after growing on solid agarose-BMM for $24 \mathrm{~h}$ at $27^{\circ} \mathrm{C}$ under continuous light conditions; scale bar $=10 \mu \mathrm{m}$.

\subsection{S. macrospora Arp1 Shows Dynamic Localization during Ascospore Germination}

Based on the localization of Arp1 in actively growing hyphae, its association with the nucleus, and its subapical localization, we assumed that it could serve as a complementing marker protein in the highly polar processes of fungal development and pathogenicity. To visualize the localization of Arp1 during the ascospore germination of $S$. macrospora, Smarp1-mNG and nuclei marked with tdTomato (RH2B) fused to histone 2B were recorded in a wild-type background (Video S4). After meiosis and a post-meiotic mitosis, the asci of S. macrospora were found to contain eight nuclei that were surrounded by the spore wall. Subsequently, iterate mitoses led to multiple nuclei in each ascospore. During germination, spores form one germination vesicle at one side of the ascospore. While the size of the germination vesicles increases, multiple nuclei of the ascospore are released to the vesicle. Finally, hyphae start growing form the germination vesicle [80].

During this highly dynamic germination process, we tracked SmArp1-mNG localization to four different sites and structures of the germination vesicle and the emerging hypha (Figure 4). First, Arp1 fluorescent signals appeared close to nuclei. Moreover, SmArp1$\mathrm{mNG}$ localized at the growing hyphal tip, moving as dot-like structures in anterograde and retrograde directions. Third, a quickly emerging and disseminating fluorescent filamentous signal appeared in the germination vesicle. Additionally, a probable microtubule organization center (MTOC) was found to dominate the germination vesicle. 


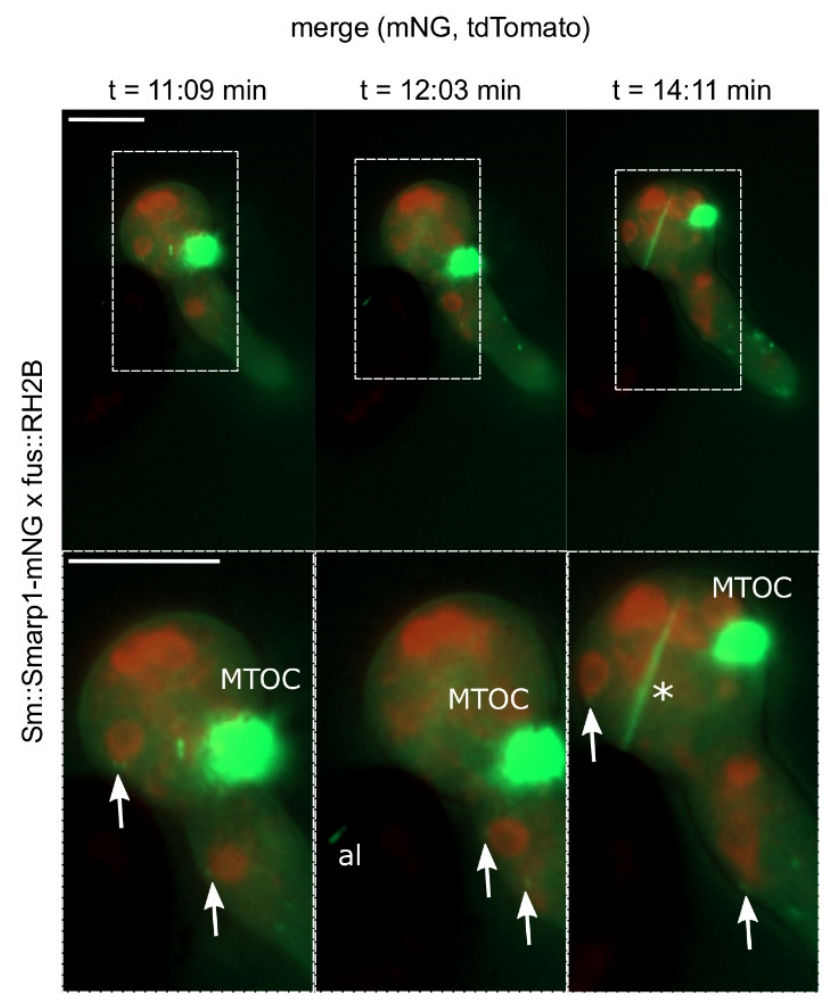

Figure 4. The dynamic localization of SmArp1-mNG in germinating S. macrospora ascospores. Selected images of Video S4, which tracks the germination of $S$. macrospora ascospores expressing Smarp1-mNG and red fluorescent histone 2B (RH2B tdTomato) on BMM-agar supplemented with agarose after incubation for $3-4 \mathrm{~h}$ at $27^{\circ} \mathrm{C}$. Arrows = localization of SmArp1-mNG close to nuclei; MTOC = putative microtubule organization center; al = SmArp1-mNG localization inside the ascospore; asterisk = SmArp1-mNG localization in fast appearing and dispersing linear structures; size bars $=10 \mu \mathrm{m}$; recording interval $=5 \mathrm{~s}$.

\subsection{Analysis of Chemotropic Growth Is Improved by the Usage of the Arp1-TagRFP-T Marker}

Chemotropic growth to nutrient sources, mating partners, and hosts is a fundamental process in fungi [6]. However, the assessment of the chemoattractive signal as well as cellular factors involved in signal recognition is not trivial. Recently, we established a new, easily applicable method using a 3D-printed device based on the chemotropic assay developed by Turrà et al., 2015 [69,81]. In our approach, growing C. graminicola germlings are confronted with a signal gradient that can be sensed over time, resulting in growth re-direction. Using a hyphal tip projection angle to a theoretical vertical line, whether a germling is growing towards the signal gradient $\left(1-179^{\circ}\right)$, is repelled by it $\left(181-359^{\circ}\right)$, or shows a neutral orientation $\left(0^{\circ} / 360^{\circ}\right.$ and $180^{\circ}$ [69]) can be determined. The application of this method results in C. graminicola germlings with a strong chemotropic growth rate when $50 \mathrm{mM}$ of glucose is used as chemoattractant, whereas the growth direction of germlings is uniform in control experiments with water, as depicted by a chemotropic rate of about $50 \%$ [69].

Despite its significance, this evaluation mode does not differentiate between germlings showing active growth re-direction due to signal sensing and germlings that stopped their growth during incubation time and are not actively sensing. Furthermore, in these experiments, we often observed germlings that grew bi-directionally, which could not be included in the evaluation since a clear readout was missing (Figure 5a). 
(a)

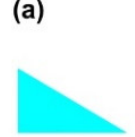

- Arp1 monitoring

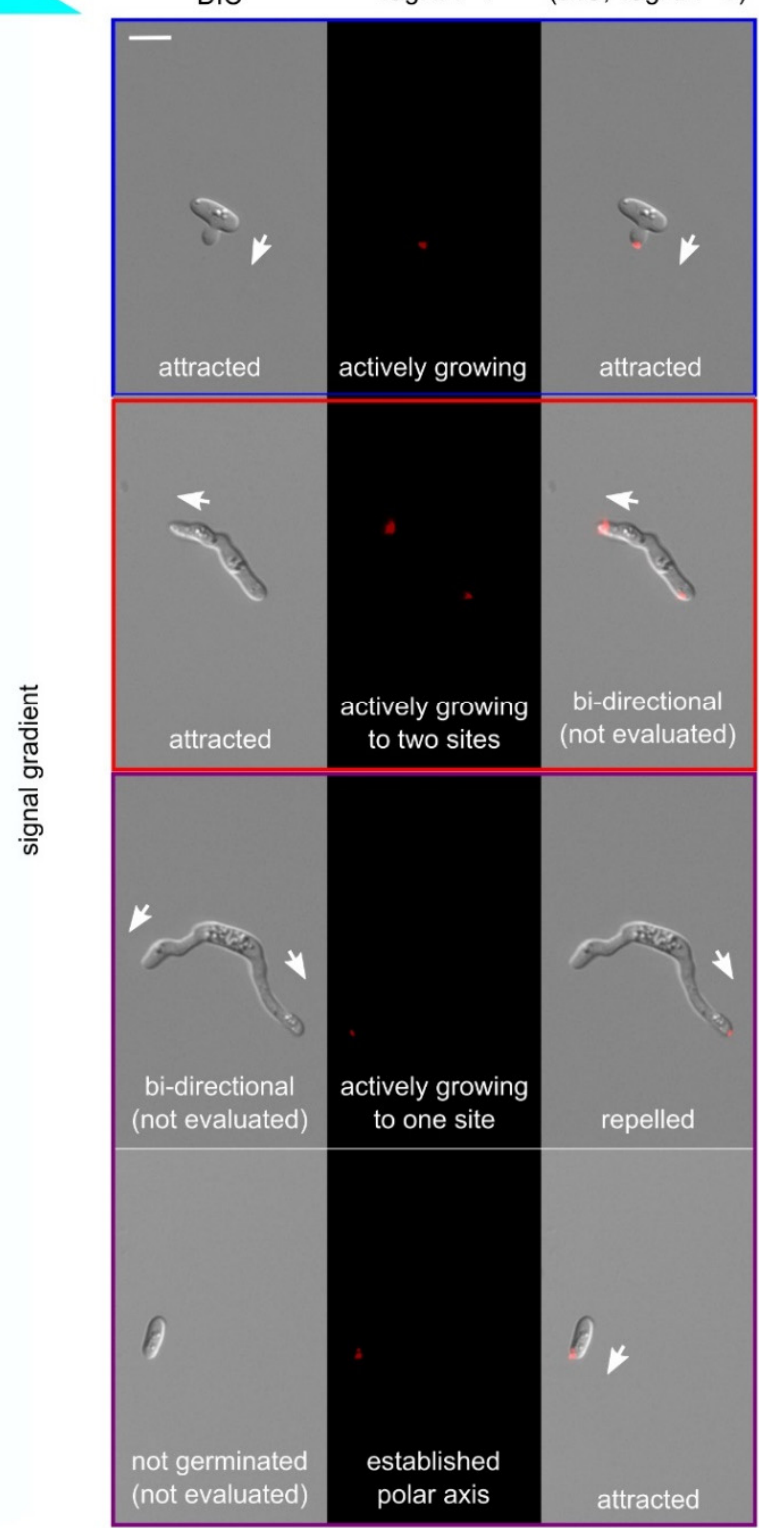

(b)

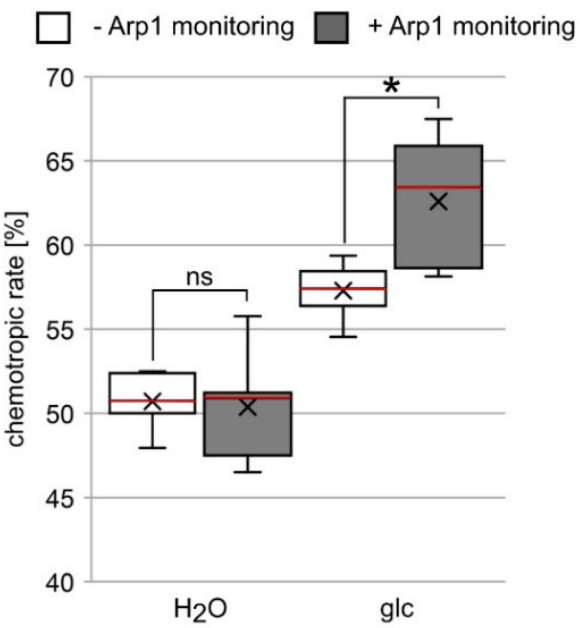

Figure 5. Enhanced evaluation of C. graminicola chemotropic growth by the application of the Arp1 marker: (a) the evaluation of growth direction of germlings based on microscopic analyses without (-) and with (+) Arp1 monitoring. The tip localization of Arp1-TagRFP-T was used as an indication for active growth or established polar axis. Blue box = same evaluation of results in $(-)$ and (+); red box = different evaluation results in $(-)$ and $(+)$; violet box = germlings or non-germinated conidia that can be included in the $(+)$ evaluation in contrast to $(-)$; size bar $=10 \mu \mathrm{m}$. (b) The chemotropic rates of germlings to gradients of water $\left(\mathrm{H}_{2} \mathrm{O}\right)$ and $50 \mathrm{mM}$ glucose (glc) after incubation for $6 \mathrm{~h}$ at $23{ }^{\circ} \mathrm{C}$ obtained from experiments without $(-)$ and with (+) the monitoring of the fluorescent Arp1 marker. Chemotropic rate: $<50 \%=$ repulsion; $=50 \%=$ no growth reaction; $>50 \%=$ attraction; meridian is indicated in red; average is indicated by $\mathrm{x} ; n \geq 5 ;{ }^{*}, p<0.05 ;$ ns $=$ not significant.

Due to correlation between Arp1 tip localization and active growth or polarity axis establishment, we tested whether the usage of the Arp1 localization marker allowed us to improve the readout quality of the chemotropic assay. As depicted in Figure 5a, the localization of CgArp1-TagRFP-T to the tip often, but not always, corresponded to growth direction. In the case of bi-directional growing germlings, it allowed us to determine the current growth direction solely indicated by CgArp1-TagRFP-T localization to one hyphal tip. Interestingly, we also found that non-germinating conidia displayed a clear CgArp1- 
RFP-T localization to one cellular site or displayed a rather scattered localization of Arp1. Anticipating the clear targeted localization to mark the current polar axis, we were also able to include those conidia into the evaluation (Figure 5a and Figure S7, and Videos S5 and S6). To test whether the integration of the CgArp1-TagRFP-T marker changed the determined chemotropic rate, we used this strain in experiments with a $50 \mathrm{mM}$ glucose gradient and experiments with no-signal control (Figure $5 b$ ). For five replicates in which at least 40 germlings were evaluated for their dominant growth direction, we monitored DIC and TagRFP-T channel information and saved them for further analysis. In a first evaluation, we referred to the information obtained from DIC channel and analyzed chemotropic growth as described earlier [69]. This quantification resulted in chemotropic rates of $50.7 \% \pm 1.7 \%$ (water control) and $57.3 \% \pm 1.6 \%$ (50 mM glucose). In a second step, we used the same microscopic pictures for a renewed evaluation, and we integrated the information gained from the Arp1 monitoring. The exclusive integration of germlings or conidia with a clear CgArp1-TagRFP-T signal in the tip or a distinct cellular site resulted in a significant increase of the chemotropic rate to $50 \mathrm{mM}$ glucose $(62.6 \% \pm 3.7 \% ; p=0.01)$, whereas no significant changes were observed in the control experiments $(50.4 \% \pm 3.3 \% ; p=0.86)$. From these results, we conclude that application of the Arp1 marker can be used to increase sensitivity to analyses of chemotropic growth.

\subsection{Tracking of Penetration Hyphae into Plant Tissue by Monitoring of Arp1 Localization in C. graminicola}

For plant pathogens such as C. graminicola, the penetration of plant tissue by appressoria emerging from conidia or hyphae-derived hyphopodia marks an early step of infection. Both appressoria and hyphopodia are specialized structures that are able to build up high turgor pressure [10]. Just prior to the penetration of a plant cell, the polarity of the penetration structure shifts to a predetermined breaking point. There, a penetration pore opens and the penetration peg emerges. In a second phase, the peg develops into a penetration hypha that pushes deeper into the plant tissue [9,82]. Since a distinct signaling network regulates penetration hyphae elongation [83,84], the tracking of its path into plant tissue might help to gain important insights about the role of certain molecular players. To test whether the Arp1 marker enables such an approach, we incubated oval conidia of CgM2::Cgarp1-TagRPF-T on a heat-inactivated onion epidermis. Using stack imaging, we were able to follow the penetration hyphae from its site of emergence into plant tissue. In addition to some dot-like, dynamic CgArp1-TagRFP-T localization patches, we observed a bright fluorescent signal at the subapical tip region, indicating the current growth direction (Figure 6 and Video S7).

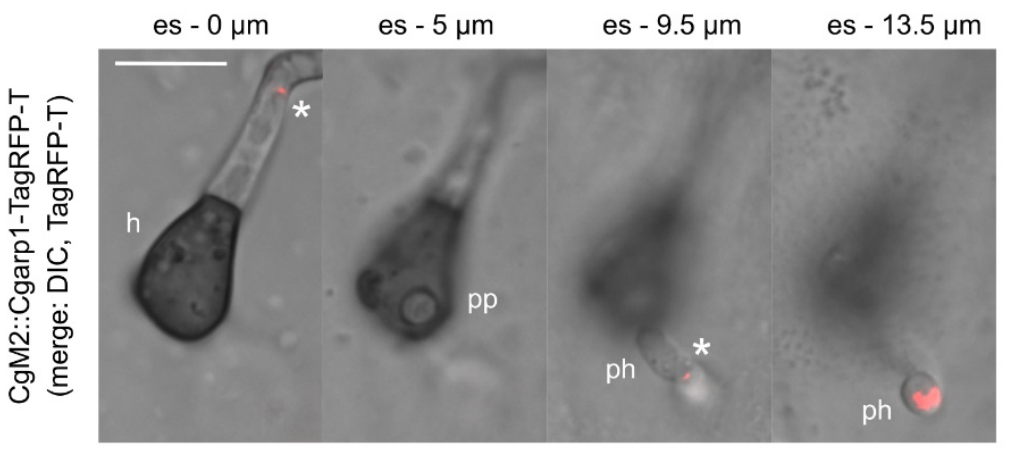

Figure 6. The visualization of penetration hyphae dynamics during onion epidermis perforation: $10^{3}$ oval conidia of C. graminicola CgM2::Cgarp1-TagRFP-T were inoculated on a heat-inactivated onion epidermis overlaying water agar for $29 \mathrm{~h}$ at $23^{\circ} \mathrm{C}$. Different layers were recorded at a fixed distance of $0.5 \mu \mathrm{m}$ originating from the epidermal surface (es). In the selected images of Video S7, size bar $=10 \mu \mathrm{m} ; \mathrm{h}=$ hyphopodium; $\mathrm{pp}=$ penetration pore; $\mathrm{ph}=$ penetration hyphae; ${ }^{*}$ non-tip localization of Arp1-TagRFP-T. 


\section{Discussion}

In most fungi, MTs are organized by the nuclear membrane-embedded spindle pole body (SPB), also referred to as the MTOC, and found as part of intranuclear spindles and tracks within the cytoplasm $[85,86]$. Consequently, we monitored fluorescently labelled dynactin complex component Arp1 at distinct sites in the filaments of germlings and mature hyphae of two ascomycetous fungi, S. macrospora and C. graminicola. Highly prominent and independent of the used fluorophore, a dynamic localization of Arp1 to the subapical part of the hyphal tip was found to be correlated with an active growth of hyphae (Figures 1 and 2). A similar localization was reported for $A$. nidulans expressing a GFP-tagged version of the dynein heavy chain $n u d A$ [87]. Additionally in axons and migrating fibroblasts during wound healing, Arp1 is enriched in the leading edge of polar growing cells [88,89]. Since the accumulation of dynactin and polarity establishment in axons and fibroblasts are simultaneous processes, it has been proposed that the dynein/dynactin complex is involved in microtubule orientation and transport rather than being a passive motor running along microtubule rails [90]. Additionally, in the corn-smut fungus Ustilago maydis, such a dependence of microtubule motility on the motor dynein was proposed [91], indicating a conservation of this interaction.

This hypothesis is consistent with the observed drastic reduced growth in $\Delta \mathrm{Smarp} 1$, a phenotype previously reported for $\Delta$ ro-4, an arp1 deletion mutant generated in $N$. crassa (Figure S4) [92]. Additionally, our Arp1 localization studies in the conidia and germlings of C. graminicola support a role for Arp1 in transport along MTs, as well as an active role in MT organization (Figure 2). In C. graminicola, we observed a shift of Arp1-TagRFP-T accumulation to a new branching site before actual growth had begun.

Likewise, in the use of the Arp1-TagRPF-T marker in chemotropic growth analyses, we observed that several conidia that had not yet been germinated showed a strong and distinct localization of Arp1 to one distinct cellular site, different to dormant conidia with a uniform Arp1 localization (Figure 5 and Figure S7). Similar observations have been made for the cell end marker tea from $A$. nidulans, which appears at the future germination site prior to germ tube formation. Tea deletion mutant analysis showed a rather uncontrolled germination pattern at multiple sites, indicating a misfunction in polarity establishment and microtubule organization [93]. Direct evidence for dynein and dynactin in microtubule organization in filamentous fungi was derived from a study by Riquelme and co-workers (2000) in which functional dynein or dynactin complexes were correlated with fast hyphal expansion, stable polar growth, and SPK assembly [94]. To characterize the localization of Arp1 in regard to the SPK, we stained hyphae of S. macrospora and C. graminicola expressing green fluorescent Arp1 with the membrane-selective dye FM4-64. Interestingly, Arp1 was found to localize just behind the SPK in both fungi and seems to be embedded within this vesicle organization's center. These observations are consistent with the role of dynein/dynactin in the retrograde transport of endosomal vesicles from the hyphal apex $[38,41,95]$. However, Arp1 and the SPK are involved in overlapping but not identical cellular functions, whereas the SPK is absent from very young germlings and correlates with germling length in $N$. crassa [96], so we also monitored fluorescent Arp1 in very young germlings of $C$. graminicola (Figure 2). Furthermore, whereas the SPK is visible at protrusions marking future cellular fusion points in N. crassa [97], we were not able to monitor fluorescent Arp1 at these cellular sites. This finding is in line with previous studies providing evidence that MTs are dispensable for germling communication and fusion in N. crassa [98]. Instead, actin patches and cables associated with endocytic vesicles and exocytosis, respectively, are enriched at germling protrusions in that fungus [98-100].

In addition to the importance of MTs for polarity establishment and growth, they also provide a basis for the transport of various cellular components [34]. Among others, they organize nuclear distribution along the hyphae $[43,101]$. In this study, we observed dynamic dot-like Arp1 patches in the mature hyphae of S. macrospora, which are associated with nuclei and nuclear movement in both hyphae (Figure 1) and germinating S. macrospora ascospores (Figure 4). Our findings are supported by an early study of Plamann and 
coworkers, in which $N$. crassa deletion mutants of dynein and dynactin components were investigated [43]. Phenotypes of both mutants defective in either the heavy chain of cytoplasmatic dynein (ro-1) or arp1 showed defects in polar growth, as well as evenly nuclear distribution along the fungal hyphae. Intriguingly, both deletion mutants showed a segmented accumulation of nuclei leaving other hyphal segments nuclei-free [43]. In A. nidulans, the coiled-coil protein ApsB is attached to the nuclei in an Arp1-like fashion during their transport along MTs and has been shown to regulate nuclear migration [101-103]. However, instead of localizing to the poles of the mitotic spindle, as with ApsB [102], fluorescent Arp1-mNG seemed to localize to the dynamic spindle itself in some cases, as well as to a probable MTOC in the germination vesicle (Figure 4). Though the localization of the dynein/dynactin complex to the spindle has been shown by various studies [104], such a dense Arp1 accumulation has not been monitored to date. However, one might speculate that this dense structure in the germination vesicle is potentially involved in the organized sorting of nuclei into the emerging hyphae and might be ascospore-specific. Intriguingly, this structure does not leave the vesicle, indicating that it might be a specific cellular structure required for ascospore germination. To investigate processes regarding ascospore germination in greater depth, further investigations are required.

\section{Conclusions}

Polar growth is critical for filamentous fungi and takes part in manifold processes determining fungal development and pathogenicity. Through detailed localization studies of the two filamentous fungi S. macrospora and C. graminicola, Arp1, we have provided evidence that the central component of dynactin marks sites of polarity establishment and active polar growth in filamentous fungi. Additionally, Arp1 attaches to nuclei and forms a so-far unknown structure that is probably involved in organelle sorting in germinating ascospores. Though fluorescently-tagged Arp1 shares some characteristics with established polarity markers, its localization shows some unique patterns, which makes this new marker valuable for the investigation of polar growth processes including chemotropic growth, plant penetration, and ascospore germination.

Supplementary Materials: The following are available online at https: / www.mdpi.com/article / 10.3390/jof7070580/s1: Figure S1: CLUSTAL Omega (1.2.4) multiple sequence alignment of fungal ARP1 orthologs; Figure S2: Phylogenetic tree of Arp1 orthologs from fungi; Figure S3: Verification of S. macrospora Smarp1 deletion by PCR and Southern blot analysis; Figure S4: Growth of S. macrospora $\Delta$ Smarp1 and complementing strains and corresponding expression controls via Western blot analysis; Figure S5: Localization of SmArp1-mNG and free mNG in S. macrospora; Figure S6: Localization of Arp1 and FM4-64 in C. graminicola. Heterologous expression of pSmarp1-mNG in C. graminicola wild-type CgM2 hyphae; Figure S7: Localization of Arp1 in unpolarized, non-germinated oval conidia of C. graminicola; Table S1: Oligonucleotides used in this study; Table S2: Plasmids used in this study; Video S1: Dynamic localization of SmArp1-mNG to growing hyphal tips; Video S2: Nuclear localization of SmArp1-mNG. Heterologous expression of pSmarp1-mNG in S. macrospora wild-type hyphae; Video S3: Dynamic localization of CgArp1-TagRFP-T in growing C. graminicola germlings; Video S4: Dynamic localization of SmArp1-mNG in S. macrospora germinating ascospores; Video S5: Establishment of a polar Arp1-TagRFP-T localization prior to germination of C. graminicola; Video S6: Tracking of Arp1-RFP-T during the germination of C. graminicola oval conidia; Video S7: Visualization of $C$. graminicola penetration hyphae dynamics during onion epidermis perforation.

Author Contributions: Conceptualization, D.E.N. and S.P.; methodology, A.G., C.S., E.J.R., and D.E.N.; validation, D.E.N., A.G., and S.P.; investigation, A.G. and D.E.N.; resources, D.E.N. and S.P.; writing—original draft preparation, A.G. and D.E.N.; writing—review and editing, A.G., C.S., E.J.R., S.P., and D.E.N.; supervision, D.E.N. and S.P.; funding acquisition, D.E.N. and S.P. All authors have read and agreed to the published version of the manuscript.

Funding: This work was funded by the Deutsche Forschungsgemeinschaft (Bonn-Bad Godesberg, projects NO 1230/3-1 (447175909) and PO 523/9-1 (429272002)). We acknowledge support by the Open Access Publication Funds of the Göttingen University. 
Institutional Review Board Statement: Not applicable.

Informed Consent Statement: Not applicable.

Data Availability Statement: The data presented in this study are available on request from the corresponding author.

Acknowledgments: We are grateful to Gertrud Stahlhut and Gabriele Beyer for excellent technical assistance. We also thank Anja Raschke, Institute for Agricultural and Nutritional Sciences, Martin-Luther-University Halle-Wittenberg, for sharing the protocol for C. graminicola onion epidermis infection.

Conflicts of Interest: The authors declare no conflict of interest. The funders had no role in the design of the study, the conducted analyses, the interpretation of data, the writing of the manuscript, or in the decision to publish the results.

\section{References}

1. Riquelme, M. Tip growth in filamentous fungi: A road trip to the apex. Annu. Rev. Microbiol. 2013, 67, 587-609. [CrossRef] [PubMed]

2. Fischer, R.; Zekert, N.; Takeshita, N. Polarized growth in fungi-interplay between the cytoskeleton, positional markers and membrane domains. Mol. Microbiol. 2008, 68, 813-826. [CrossRef]

3. Mela, A.P.; Rico-Ramírez, A.M.; Glass, N.L. Syncytia in Fungi. Cells 2020, 9, 2255. [CrossRef]

4. Lichius, A.; Lord, K.M. Chemoattractive mechanisms in filamentous fungi. Open Mycol. J. 2014, 8, 28-57. [CrossRef]

5. Brand, A.; Gow, N.A. Mechanisms of hypha orientation of fungi. Curr. Opin. Microbiol. 2009, 12, 350-357. [CrossRef] [PubMed]

6. Turrà, D.; Nordzieke, D.; Vitale, S.; El Ghalid, M.; Di Pietro, A. Hyphal chemotropism in fungal pathogenicity. Semin. Cell Dev. Biol. 2016, 57, 69-75. [CrossRef] [PubMed]

7. Becker, M.; Becker, Y.; Green, K.; Scott, B. The endophytic symbiont Epichloe festucae establishes an epiphyllous net on the surface of Lolium perenne leaves by development of an expressorium, an appressorium-like leaf exit structure. New Phytol. 2016, 211, 240-254. [CrossRef]

8. Zhao, Y.L.; Zhou, T.T.; Guo, H.S. Hyphopodium-specific VdNoxB/VdPls1-Dependent ROS-Ca ${ }^{2+}$ signaling is required for plant infection by Verticillium dahliae. PLoS Pathog. 2016, 12, e1005793. [CrossRef]

9. Ryder, L.S.; Talbot, N.J. Regulation of appressorium development in pathogenic fungi. Curr. Opin. Plant Biol. 2015, 26, 8-13. [CrossRef]

10. Werner, S.; Sugui, J.A.; Steinberg, G.; Deising, H.B. A chitin synthase with a myosin-like motor domain is essential for hyphal growth, appressorium differentiation, and pathogenicity of the maize anthracnose fungus Colletotrichum graminicola. Mol. Plant Microbe Interact. 2007, 20, 1555-1567. [CrossRef]

11. Riquelme, M.; Aguirre, J.; Bartnicki-García, S.; Braus, G.H.; Feldbrügge, M.; Fleig, U.; Hansberg, W.; Herrera-Estrella, A.; Kamper, J.; Kück, U.; et al. Fungal morphogenesis, from the polarized growth of hyphae to complex reproduction and infection structures. Microbiol. Mol. Biol. Rev. 2018, 82, e00068-17. [CrossRef]

12. Higuchi, Y.; Shoji, J.Y.; Arioka, M.; Kitamoto, K. Endocytosis is crucial for cell polarity and apical membrane recycling in the filamentous fungus Aspergillus oryzae. Eukaryot. Cell 2009, 8, 37-46. [CrossRef]

13. Momany, M. Polarity in filamentous fungi: Establishment, maintenance and new axes. Curr. Opin. Microbiol. $2002,5,580-585$. [CrossRef]

14. Riquelme, M.; Martínez-Núñez, L. Hyphal ontogeny in Neurospora crassa: A model organism for all seasons. F1000Research 2016, 5, 2801. [CrossRef] [PubMed]

15. Wendland, J.; Philippsen, P. Cell polarity and hyphal morphogenesis are controlled by multiple rho-protein modules in the filamentous ascomycete Ashbya gossypii. Genetics 2001, 157, 601-610. [CrossRef] [PubMed]

16. Woods, B.; Lew, D.J. Polarity establishment by Cdc42: Key roles for positive feedback and differential mobility. Small GTPases 2019, 10, 130-137. [CrossRef] [PubMed]

17. Miller, K.E.; Kang, P.J.; Park, H.-O. Regulation of Cdc42 for polarized growth in budding yeast. Microb. Cell 2020, 7, 175. [CrossRef] [PubMed]

18. Harris, S.D. Cdc42/Rho GTPases in fungi: Variations on a common theme. Mol. Microbiol. 2011, 79, 1123-1127. [CrossRef]

19. Drees, B.L.; Sundin, B.; Brazeau, E.; Caviston, J.P.; Chen, G.C.; Guo, W.; Kozminski, K.G.; Lau, M.W.; Moskow, J.J.; Tong, A.; et al. A protein interaction map for cell polarity development. J. Cell Biol. 2001, 154, 549-571. [CrossRef] [PubMed]

20. Martin, S.G.; Arkowitz, R.A. Cell polarization in budding and fission yeasts. FEMS Microbiol. Rev. 2014, 38, 228-253. [CrossRef]

21. Sharpless, K.E.; Harris, S.D. Functional characterization and localization of the Aspergillus nidulans formin SEPA. Mol. Biol. Cell 2002, 13, 469-479. [CrossRef] [PubMed]

22. Lichius, A.; Yáñez-Gutiérrez, M.E.; Read, N.D.; Castro-Longoria, E. Comparative live-cell imaging analyses of SPA-2, BUD-6 and BNI-1 in Neurospora crassa reveal novel features of the filamentous fungal polarisome. PLoS ONE 2012, 7, e30372. [CrossRef]

23. Giesbert, S.; Siegmund, U.; Schumacher, J.; Kokkelink, L.; Tudzynski, P. Functional analysis of BcBem1 and its interaction partners in Botrytis cinerea: Impact on differentiation and virulence. PLoS ONE 2014, 9, e95172. [CrossRef] [PubMed] 
24. Harris, S.D.; Hamer, L.; Sharpless, K.E.; Hamer, J.E. The Aspergillus nidulans sepA gene encodes an FH1/2 protein involved in cytokinesis and the maintenance of cellular polarity. EMBO J. 1997, 16, 3474-3483. [CrossRef] [PubMed]

25. Lichius, A.; Goryachev, A.B.; Fricker, M.D.; Obara, B.; Castro-Longoria, E.; Read, N.D. CDC-42 and RAC-1 regulate opposite chemotropisms in Neurospora crassa. J. Cell Sci. 2014, 127, 1953-1965. [CrossRef] [PubMed]

26. Zheng, P.; Nguyen, T.A.; Wong, J.Y.; Lee, M.; Nguyen, T.A.; Fan, J.S.; Yang, D.; Jedd, G. Spitzenkörper assembly mechanisms reveal conserved features of fungal and metazoan polarity scaffolds. Nat. Commun. 2020, 11, 2830. [CrossRef] [PubMed]

27. Steinberg, G. Hyphal growth: A tale of motors, lipids, and the Spitzenkörper. Eukaryot. Cell 2007, 6, 351-360. [CrossRef] [PubMed]

28. Harris, S.D.; Read, N.D.; Roberson, R.W.; Shaw, B.; Seiler, S.; Plamann, M.; Momany, M. Polarisome meets Spitzenkörper: Microscopy, genetics, and genomics converge. Eukaryot. Cell 2005, 4, 225-229. [CrossRef]

29. Wendland, J.; Walther, A. Ashbya gossypii: A model for fungal developmental biology. Nat. Rev. Microbiol. 2005, 3, 421-429. [CrossRef] [PubMed]

30. Mouriño-Pérez, R.R.; Roberson, R.W.; Bartnicki-García, S. Microtubule dynamics and organization during hyphal growth and branching in Neurospora crassa. Fungal Genet. Biol. 2006, 43, 389-400. [CrossRef] [PubMed]

31. Konzack, S.; Rischitor, P.E.; Enke, C.; Fischer, R. The role of the kinesin motor KipA in microtubule organization and polarized growth of Aspergillus nidulans. Mol. Biol. Cell 2005, 16, 497-506. [CrossRef]

32. Steinberg, G.; Peñalva, M.A.; Riquelme, M.; Wösten, H.A.; Harris, S.D. Cell biology of hyphal growth. Microbiol. Spectr. 2017, 5, FUNK-0034-2016. [CrossRef]

33. Holleran, E.A.; Ligon, L.A.; Tokito, M.; Stankewich, M.C.; Morrow, J.S.; Holzbaur, E.L. $\beta$ III spectrin binds to the Arp1 subunit of dynactin. J. Biol. Chem. 2001, 276, 36598-36605. [CrossRef] [PubMed]

34. Reck-Peterson, S.L.; Redwine, W.B.; Vale, R.D.; Carter, A.P. The cytoplasmic dynein transport machinery and its many cargoes. Nat. Rev. Mol. Cell Biol. 2018, 19, 382-398. [CrossRef] [PubMed]

35. Eckley, D.M.; Schroer, T.A. Interactions between the evolutionarily conserved, actin-related protein, Arp11, actin, and Arp1. Mol. Biol. Cell 2003, 14, 2645-2654. [CrossRef] [PubMed]

36. Christopher, L.; Fletcher, L.; Dykstra, C. Cloning and Identification of Arp1, an Actin-Related Protein from Pneumocystis carinii. J. Eukaryot. Microbiol. 1995, 42, 142-149. [CrossRef]

37. Schafer, D.; Gill, S.R.; Cooper, J.; Heuser, J.; Schroer, T. Ultrastructural analysis of the dynactin complex: An actin-related protein is a component of a filament that resembles F-actin. J. Cell Biol. 1994, 126, 403-412. [CrossRef] [PubMed]

38. Lenz, J.H.; Schuchardt, I.; Straube, A.; Steinberg, G. A dynein loading zone for retrograde endosome motility at microtubule plus-ends. EMBO J. 2006, 25, 2275-2286. [CrossRef]

39. Egan, M.J.; Tan, K.; Reck-Peterson, S.L. Lis1 is an initiation factor for dynein-driven organelle transport. J. Cell Biol. 2012, 197, 971-982. [CrossRef]

40. Zhang, J.; Li, S.; Fischer, R.; Xiang, X. Accumulation of cytoplasmic dynein and dynactin at microtubule plus ends in Aspergillus nidulans is kinesin dependent. Mol. Biol. Cell 2003, 14, 1479-1488. [CrossRef] [PubMed]

41. Schuster, M.; Kilaru, S.; Ashwin, P.; Lin, C.; Severs, N.J.; Steinberg, G. Controlled and stochastic retention concentrates dynein at microtubule ends to keep endosomes on track. EMBO J. 2011, 30, 652-664. [CrossRef] [PubMed]

42. Eckley, D.M.; Gill, S.R.; Melkonian, K.A.; Bingham, J.B.; Goodson, H.V.; Heuser, J.E.; Schroer, T.A. Analysis of dynactin subcomplexes reveals a novel actin-related protein associated with the arp1 minifilament pointed end. J. Cell Biol. 1999, 147, 307-320. [CrossRef] [PubMed]

43. Plamann, M.; Minke, P.F.; Tinsley, J.H.; Bruno, K.S. Cytoplasmic dynein and actin-related protein Arp1 are required for normal nuclear distribution in filamentous fungi. J. Cell Biol. 1994, 127, 139-149. [CrossRef] [PubMed]

44. Sambrook, J.; Fritsch, E.; Maniatis, T. (Eds.) Molecular Cloning: A Laboratory Manual; Cold Spring Harbor Laboratory Press: Cold Spring Harbor, NY, USA, 2001.

45. Colot, H.V.; Park, G.; Turner, G.E.; Ringelberg, C.; Crew, C.M.; Litvinkova, L.; Weiss, R.L.; Borkovich, K.A.; Dunlap, J.C. A high-throughput gene knockout procedure for Neurospora reveals functions for multiple transcription factors. Proc. Natl. Acad. Sci. USA 2006, 103, 10352-10357. [CrossRef]

46. James, P.; Halladay, J.; Craig, E.A. Genomic libraries and a host strain designed for highly efficient two-hybrid selection in yeast. Genetics 1996, 144, 1425-1436. [CrossRef]

47. Walz, M.; Kück, U. Transformation of Sordaria macrospora to hygromycin B resistance: Characterization of transformants by electrophoretic karyotyping and tetrad analysis. Curr. Genet. 1995, 29, 88-95. [CrossRef]

48. Elleuche, S.; Pöggeler, S. Visualization of peroxisomes via SKL-tagged DsRed protein in Sordaria macrospora. Fungal Genet. Rep. 2008, 55, 9-12. [CrossRef]

49. Esser, K. Cryptogams_Cyanobacteria, Algae, Fungi, Lichens; Cambridge University Press: London, UK, 1982.

50. Nowrousian, M.; Ringelberg, C.; Dunlap, J.C.; Loros, J.J.; Kück, U. Cross-species microarray hybridization to identify developmentally regulated genes in the filamentous fungus Sordaria macrospora. Mol. Genet. Genom. 2005, 273, 137-149. [CrossRef]

51. Bernhards, Y.; Pöggeler, S. The phocein homologue SmMOB3 is essential for vegetative cell fusion and sexual development in the filamentous ascomycete Sordaria macrospora. Curr. Genet. 2011, 57, 133-149. [CrossRef]

52. O'Connell, R.J.; Thon, M.R.; Hacquard, S.; Amyotte, S.G.; Kleemann, J.; Torres, M.F.; Damm, U.; Buiate, E.A.; Epstein, L.; Alkan, N.; et al. Lifestyle transitions in plant pathogenic Colletotrichum fungi deciphered by genome and transcriptome analyses. Nat. Genet. 2012, 44, 1060-1065. [CrossRef] 
53. Nordzieke, D.E.; Sanken, A.; Antelo, L.; Raschke, A.; Deising, H.B.; Pöggeler, S. Specialized infection strategies of falcate and oval conidia of Colletotrichum graminicola. Fungal Genet. Biol. 2019, 133, 103276. [CrossRef]

54. Katoh, K.; Rozewicki, J.; Yamada, K.D. MAFFT online service: Multiple sequence alignment, interactive sequence choice and visualization. Brief. Bioinform. 2019, 20, 1160-1166. [CrossRef]

55. Han, M.V.; Zmasek, C.M. phyloXML: XML for evolutionary biology and comparative genomics. BMC Bioinform. 2009, 10, 1-6. [CrossRef]

56. Reschka, E.J.; Nordzieke, S.; Valerius, O.; Braus, G.H.; Pöggeler, S. A novel STRIPAK complex component mediates hyphal fusion and fruiting-body development in filamentous fungi. Mol. Microbiol. 2018, 110, 513-532. [CrossRef]

57. Dahlmann, T.A.; Terfehr, D.; Becker, K.; Teichert, I. Golden Gate vectors for efficient gene fusion and gene deletion in diverse filamentous fungi. Curr. Genet. 2021, 67, 317-330. [CrossRef]

58. Klix, V.; Nowrousian, M.; Ringelberg, C.; Loros, J.J.; Dunlap, J.C.; Pöggeler, S. Functional characterization of MAT1-1-specific mating-type genes in the homothallic ascomycete Sordaria macrospora provides new insights into essential and nonessential sexual regulators. Eukaryot. Cell 2010, 9, 894-905. [CrossRef] [PubMed]

59. Werner, A.; Otte, K.L.; Stahlhut, G.; Pöggeler, S. Establishment of the monomeric yellow-green fluorescent protein mNeonGreen for life cell imaging in mycelial fungi. AMB Express 2020, 10, 222. [CrossRef] [PubMed]

60. Pöggeler, S.; Masloff, S.; Hoff, B.; Mayrhofer, S.; Kück, U. Versatile EGFP reporter plasmids for cellular localization of recombinant gene products in filamentous fungi. Curr. Genet. 2003, 43, 54-61. [CrossRef]

61. Werner, A.; Otte, K.; Stahlhut, G.; Hanke, L.M.; Pöggeler, S. The glyoxysomal protease LON2 is involved in fruiting-body development, ascosporogenesis and stress resistance in Sordaria macrospora. J. Fungi 2021, 7, 82. [CrossRef]

62. Bloemendal, S.; Bernhards, Y.; Bartho, K.; Dettmann, A.; Voigt, O.; Teichert, I.; Seiler, S.; Wolters, D.A.; Pöggeler, S.; Kück, U. A homologue of the human STRIPAK complex controls sexual development in fungi. Mol. Microbiol. 2012, 84, 310-323. [CrossRef] [PubMed]

63. Shibayama, M.; Ooi, K.; Johnson, R.; Scott, B.; Itoh, Y. Suppression of tandem-multimer formation during genetic transformation of the mycotoxin-producing fungus Penicillium paxilli by disrupting an orthologue of Aspergillus nidulans uvsC. Curr. Genet. 2002, 42, 59-65. [CrossRef]

64. Nowrousian, M.; Teichert, I.; Masloff, S.; Kück, U. Whole-genome sequencing of Sordaria macrospora mutants identifies developmental genes. G3 Genes Genomes Genet. 2012, 2, 261-270.

65. Nordzieke, S.; Zobel, T.; Franzel, B.; Wolters, D.A.; Kück, U.; Teichert, I. A fungal sarcolemmal membrane-associated protein (SLMAP) homolog plays a fundamental role in development and localizes to the nuclear envelope, endoplasmic reticulum, and mitochondria. Eukaryot. Cell 2015, 14, 345-358. [CrossRef] [PubMed]

66. Pöggeler, S.; Kück, U. Highly efficient generation of signal transduction knockout mutants using a fungal strain deficient in the mammalian ku70 ortholog. Gene 2006, 378, 1-10. [CrossRef] [PubMed]

67. Forgey, W.M.; Blanco, M.H.; Loegering, W.Q. Differences in pathological capabilities and host specificity of Colletotrichum graminicola on Zea mays. Plant Dis. Rep. 1978, 62, 573-576.

68. Horbach, R.; Graf, A.; Weihmann, F.; Antelo, L.; Mathea, S.; Liermann, J.C.; Opatz, T.; Thines, E.; Aguirre, J.; Deising, H.B. Sfp-type 4'-phosphopantetheinyl transferase is indispensable for fungal pathogenicity. Plant Cell 2009, 21, 3379-3396. [CrossRef] [PubMed]

69. Schunke, C.; Pöggeler, S.; Nordzieke, D.E. A 3D printed device for easy and reliable quantification of fungal chemotropic growth. Front. Microbiol. 2020, 11, 584525. [CrossRef]

70. Towbin, H.; Staehelin, T.; Gordon, J. Electrophoretic transfer of proteins from polyacrylamide gels to nitrocellulose sheets: Procedure and some applications. Proc. Natl. Acad. Sci. USA 1979, 76, 4350-4354. [CrossRef] [PubMed]

71. Schindelin, J.; Arganda-Carreras, I.; Frise, E.; Kaynig, V.; Longair, M.; Pietzsch, T.; Preibisch, S.; Rueden, C.; Saalfeld, S.; Schmid, B Fiji: An open-source platform for biological-image analysis. Nat. Methods 2012, 9, 676-682. [CrossRef]

72. Fleissner, A.; Herzog, S. Signal exchange and integration during self-fusion in filamentous fungi. Semin. Cell Dev. Biol. 2016, 57, 76-83. [CrossRef]

73. Read, N.D.; Goryachev, A.B.; Lichius, A. The mechanistic basis of self-fusion between conidial anastomosis tubes during fungal colony initiation. Fungal Biol. Rev. 2012, 26, 1-11. [CrossRef]

74. Grove, S.N.; Bracker, C.E. Protoplasmic organization of hyphal tips among fungi: Vesicles and Spitzenkörper. J. Bacteriol. 1970, 104, 989-1009. [CrossRef] [PubMed]

75. Löpez-Franco, R.; Bracker, C.E. Diversity and dynamics of the Spitzenkörper in growing hyphal tips of higher fungi. J. Bacteriol. 1996, 195, 90-111.

76. Virag, A.; Harris, S.D. The Spitzenkörper: A molecular perspective. Mycol. Res. 2006, 110, 4-13. [CrossRef]

77. Riquelme, M.; Reynaga-Peña, C.G.; Gierz, G.; Bartnicki-García, S. What determines growth direction in fungal hyphae? Fungal Genet. Biol. 1998, 24, 101-109. [CrossRef]

78. Peñalva, M.A. Tracing the endocytic pathway of Aspergillus nidulans with FM4-64. Fungal Genet. Biol. 2005, 42, 963-975. [CrossRef]

79. Fischer-Parton, S.; Parton, R.; Hickey, P.; Dijksterhuis, J.; Atkinson, H.; Read, N. Confocal microscopy of FM4-64 as a tool for analysing endocytosis and vesicle trafficking in living fungal hyphae. J. Microsc. 2000, 198, 246-259. [CrossRef]

80. Teichert, I. Nuclear dynamics during ascospore germination in Sordaria macrospora. Fungal Genet. Biol. 2017, 98, 20-22. [CrossRef] [PubMed] 
81. Turrà, D.; El Ghalid, M.; Rossi, F.; Di Pietro, A. Fungal pathogen uses sex pheromone receptor for chemotropic sensing of host plant signals. Nature 2015, 527, 521-524. [CrossRef]

82. Mendgen, K.; Hahn, M.; Deising, H. Morphogenesis and mechanisms of penetration by plant pathogenic fungi. Annu. Rev. Phytopathol. 1996, 34, 367-386. [CrossRef] [PubMed]

83. Ryder, L.S.; Dagdas, Y.F.; Mentlak, T.A.; Kershaw, M.J.; Thornton, C.R.; Schuster, M.; Chen, J.; Wang, Z.; Talbot, N.J. NADPH oxidases regulate septin-mediated cytoskeletal remodeling during plant infection by the rice blast fungus. Proc. Natl. Acad. Sci. USA 2013, 110, 3179-3184. [CrossRef] [PubMed]

84. Brun, S.; Malagnac, F.; Bidard, F.; Lalucque, H.; Silar, P. Functions and regulation of the Nox family in the filamentous fungus Podospora anserina: A new role in cellulose degradation. Mol. Microbiol. 2009, 74, 480-496. [CrossRef] [PubMed]

85. Oakley, B.R.; Oakley, C.E.; Yoon, Y.; Jung, M.K. $\gamma$-Tubulin is a component of the spindle pole body that is essential for microtubule function in Aspergillus nidulans. Cell 1990, 61, 1289-1301. [CrossRef]

86. Takeshita, N.; Manck, R.; Grün, N.; de Vega, S.H.; Fischer, R. Interdependence of the actin and the microtubule cytoskeleton during fungal growth. Curr. Opin. Microbiol. 2014, 20, 34-41. [CrossRef]

87. Xiang, X.; Han, G.; Winkelmann, D.A.; Zuo, W.; Morris, N.R. Dynamics of cytoplasmic dynein in living cells and the effect of a mutation in the dynactin complex actin-related protein Arp1. Curr. Biol. 2000, 10, 603-606. [CrossRef]

88. Baas, P.W.; Lin, S. Hooks and comets: The story of microtubule polarity orientation in the neuron. Dev. Neurobiol. 2011, 71, 403-418. [CrossRef]

89. Dujardin, D.L.; Barnhart, L.E.; Stehman, S.A.; Gomes, E.R.; Gundersen, G.G.; Vallee, R.B. A role for cytoplasmic dynein and LIS1 in directed cell movement. J. Cell Biol. 2003, 163, 1205-1211. [CrossRef]

90. Baas, P.W.; Vidya, N.C.; Myers, K.A. Axonal transport of microtubules: The long and short of it. Traffic 2006, 7, 490-498. [CrossRef]

91. Fink, G.; Steinberg, G. Dynein-dependent motility of microtubules and nucleation sites supports polarization of the tubulin array in the fungus Ustilago maydis. Mol. Biol. Cell 2006, 17, 3242-3253. [CrossRef] [PubMed]

92. Minke, P.; Lee, I.; Tinsley, J.; Plamann, M. A Neurospora crassa Arp1 mutation affecting cytoplasmic dynein and dynactin localization. Mol. Gen. Genet. MGG 2000, 264, 433-440. [CrossRef] [PubMed]

93. Takeshita, N.; Fischer, R. On the role of microtubules, cell end markers, and septal microtubule organizing centres on site selection for polar growth in Aspergillus nidulans. Fungal Biol. 2011, 115, 506-517. [CrossRef] [PubMed]

94. Riquelme, M.; Gierz, G.; Bartnicki-García, S. Dynein and dynactin deficiencies affect the formation and function of the Spitzenkörper and distort hyphal morphogenesis of Neurospora crassa. Microbiology 2000, 146, 1743-1752. [CrossRef]

95. Steinberg, G. On the move: Endosomes in fungal growth and pathogenicity. Nat. Rev. Microbiol. 2007, 5, 309-316. [CrossRef]

96. Araujo-Palomares, C.L.; Castro-Longoria, E.; Riquelme, M. Ontogeny of the Spitzenkörper in germlings of Neurospora crassa. Fungal Genet. Biol. 2007, 44, 492-503. [CrossRef]

97. Hickey, P.C.; Jacobson, D.; Read, N.D.; Glass, N.L. Live-cell imaging of vegetative hyphal fusion in Neurospora crassa. Fungal Genet Biol. 2002, 37, 109-119. [CrossRef]

98. Roca, M.G.; Kuo, H.C.; Lichius, A.; Freitag, M.; Read, N.D. Nuclear dynamics, mitosis, and the cytoskeleton during the early stages of colony initiation in Neurospora crassa. Eukaryot. Cell 2010, 9, 1171-1183. [CrossRef] [PubMed]

99. Berepiki, A.; Lichius, A.; Shoji, J.Y.; Tilsner, J.; Read, N.D. F-actin dynamics in Neurospora crassa. Eukaryot. Cell 2010, 9, 547-557. [CrossRef] [PubMed]

100. Fischer, M.S.; Glass, N.L. Communicate and fuse: How filamentous fungi establish and maintain an interconnected mycelial network. Front. Microbiol. 2019, 10, 619. [CrossRef] [PubMed]

101. Suelmann, R.; Sievers, N.; Fischer, R. Nuclear traffic in fungal hyphae: In vivo study of nuclear migration and positioning in Aspergillus nidulans. Mol. Microbiol. 1997, 25, 757-769. [CrossRef] [PubMed]

102. Veith, D.; Scherr, N.; Efimov, V.P.; Fischer, R. Role of the spindle-pole-body protein ApsB and the cortex protein ApsA in microtubule organization and nuclear migration in Aspergillus nidulans. J. Cell Sci. 2005, 118, 3705-3716. [CrossRef]

103. Fischer, R.; Timberlake, W.E. Aspergillus nidulans apsA (anucleate primary sterigmata) encodes a coiled-coil protein required for nuclear positioning and completion of asexual development. J. Cell Biol. 1995, 128, 485-498. [CrossRef] [PubMed]

104. Steuer, E.R.; Wordeman, L.; Schroer, T.A.; Sheetz, M.P. Localization of cytoplasmic dynein to mitotic spindles and kinetochores. Nature 1990, 345, 266-268. [CrossRef] [PubMed] 